This PDF is a selection from a published volume from the National Bureau of Economic Research

Volume Title: Social Security Programs and Retirement around the World: Micro-Estimation

Volume Author/Editor: Jonathan Gruber and David A. Wise, editors

Volume Publisher: University of Chicago Press

Volume ISBN: 0-226-31018-3

Volume URL: http://www.nber.org/books/grub04-1

Publication Date: January 2004

Title: The Effect of Social Security on Retirement in the United States

Author: Courtney Coile, Jonathan Gruber

URL: http://www.nber.org/chapters/c10710 


\title{
The Effect of Social Security on Retirement in the United States
}

\author{
Courtney Coile and Jonathan Gruber
}

\subsection{Introduction}

One of the most striking labor force phenomena of the second half of the twentieth century in the United States has been the rapid decline in the labor force participation rate of older men. In 1950, for example, 81 percent of sixty-two-year-old men were in the labor force; by 1995, this figure had fallen to 51 percent, although it has rebounded slightly in the past few years (Quinn 1999). Over the same period, the labor force participation rate of older women has risen dramatically, as shown in figure 12.1, due in large part to changing roles and opportunities for women during the period.

Much has been written about the proximate causes of the decline in older men's labor force participation and, in particular, about the role of the Social Security (SS) program. A large number of articles have documented pronounced "spikes" in retirement at ages sixty-two and sixty-five, which correspond to the early and normal retirement ages for SS, respectively. While there are some other explanations for a spike at age sixty-five, such as entitlement for health insurance under the Medicare program or rounding error in surveys, there is little reason to see a spike at sixty-two as

Courtney Coile is assistant professor of economics at Wellesley College and a faculty research fellow of the National Bureau of Economic Research (NBER). Jonathan Gruber is professor of economics at MIT, director of the research program on children at NBER, and research associate of NBER.

We are grateful to Dean Karlan for research assistance and to Peter Diamond, Alan Gustman, Jim Poterba, Andrew Samwick, and seminar participants at MIT, Harvard, NBER, and the Social Security Administration for helpful comments, and especially to David Wise and other participants in the International Social Security Comparisons project for their insights. Coile gratefully acknowledges support from the National Institute on Aging through NBER. Gruber acknowledges support from the National Institute on Aging. 


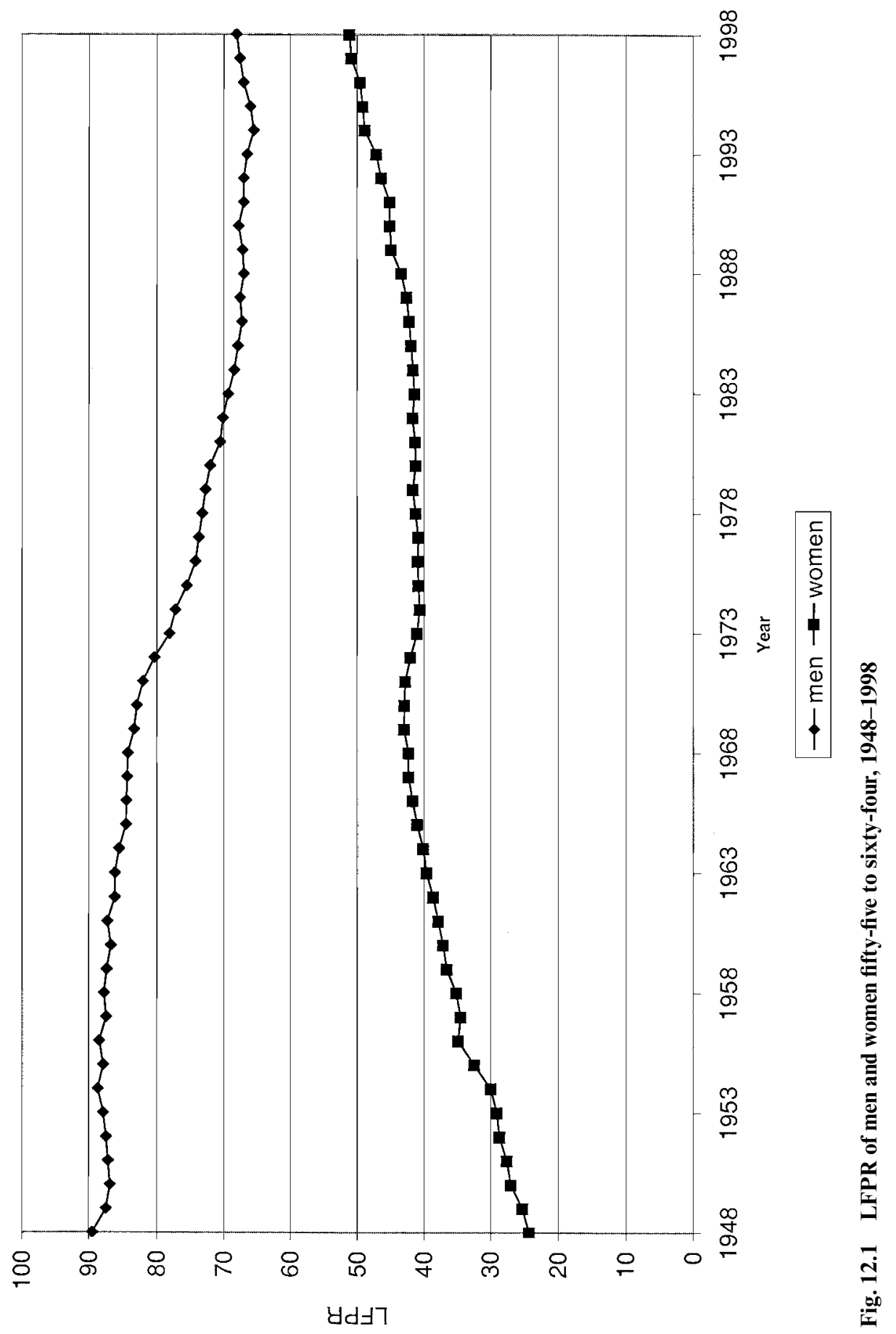


attributable to anything other than the SS program. Indeed, as Burtless and Moffitt (1984) document, this spike at age sixty-two only emerged after the early retirement eligibility age for men was introduced in 1961.

The presence of these strong patterns in retirement data suggest that the underlying structure of SS plays a critical role in determining retirement decisions, but the impact of increases in SS generosity on retirement decisions is less obvious. A large body of literature dating from the mid-1970s has investigated this relationship, and the broad conclusion of that literature is that the level of SS benefits has a significant, but modest, effect on retirement dates. However, much of this literature either relies on data that are now decades old or otherwise flawed or it suffers from methodological problems.

The purpose of our paper is to revisit the impact of SS on retirement, taking advantage of newly available data on retirement behavior and methodological advances in retirement modeling over the past decade. Our data set, the Health and Retirement Study (HRS), follows a sample of nearretirement-age individuals starting in 1992 and contains detailed information on demographic and job characteristics, labor force attachment, earnings histories, health, and private pensions.

Our empirical analysis relies on the important observation of Stock and Wise $(1990 \mathrm{a}, \mathrm{b})$ that it is not simply the level of retirement wealth or the increment with one additional year of work that matters, but the entire evolution of future wealth with further work. Their "option value" model posited retirement decisions as a function of the difference between the utility of retirement at the current date and at the date that maximizes one's utility. We use this model in a reduced-form context, as well as an alternative forward-looking measure called "peak value," introduced in Coile and Gruber (2001) and described in more detail below.

We have two major findings. First, retirement appears to respond much more to SS incentive variables defined with reference to the entire future stream of retirement incentives than to the accrual in retirement wealth over the next year alone, indicating that it is important to include forwardlooking measures such as peak value or option value in retirement models. These forward-looking measures have a significant impact on retirement decisions for men, although for women only the option value model generates a significant result. Second, we conduct simulations of the effect of two possible policy changes - raising the early and normal retirement ages by three years or moving to a system with a flat benefit of 60 percent of earnings - and find that these policy changes could have significant effects on retirement behavior.

Our paper proceeds as follows. In section 12.2, we briefly discuss the relevant institutional features of the SS system in the United States and provide an overview of the previous literature in this area. In section 12.3, we describe our data and incentive variable calculations. In section 12.4, we 
describe the empirical framework for our regression analysis and present the results of our estimation. In section 12.5, we conduct a series of simulation exercises to assess the impact of SS reform using our model, and we present our conclusions in section 12.6.

\subsection{Background}

\subsubsection{Institutional Features of Social Security}

The SS system is financed by a payroll tax that is levied equally on workers and firms. The total payroll tax paid by each party is 7.65 percentage points; 5.3 percentage points are devoted to the Old Age and Survivors Insurance (OASI) program, with 0.9 percentage points funding the Disability Insurance (DI) system and 1.45 percentage points funding Medicare's Hospital Insurance (HI) program. The payroll tax that funds OASI and DI is levied on earnings up to the taxable maximum, $\$ 76,200$ in 2000; the HI tax is uncapped.

Individuals qualify for an OASI pension by working for forty quarters in covered employment, which now encompasses most sectors of the economy. Benefits are determined in several steps. The first step is computation of the worker's averaged indexed monthly earnings (AIME), which is onetwelfth of the average of the worker's annual earnings in covered employment, indexed by a national wage index. Importantly, additional higherearnings years can replace earlier lower-earnings years, since only the highest thirty-five years of earnings are used in the calculation. ${ }^{1}$

The next step is to convert the AIME into the primary insurance amount (PIA). This is done by applying a three-piece linear progressive schedule to an individual's average earnings, whereby 90 cents of the first dollar of earnings is converted to benefits, while only 15 cents of the last dollar of earnings (up to the taxable maximum) is so converted. As a result, the rate at which SS replaces past earnings (the "replacement rate") falls with the level of lifetime earnings.

The final step is to adjust the PIA based on the age at which benefits are first claimed. For workers commencing benefit receipt at the normal retirement age (NRA; legislated to rise slowly from age sixty-five to sixtyseven over the next twenty years), the monthly benefit is the PIA. For workers claiming before the NRA, benefits are decreased by an actuarial reduction factor of five-ninths of one percent per month; thus, a worker

1. While earnings through age fifty-nine are converted to real dollars for averaging, earnings after age sixty are treated nominally. There is a two-year lag in availability of the wage index, calling for a base in the year in which the worker turns sixty in order to be able to compute benefits for workers retiring at their sixty-second birthdays. This implies particularly large effects of this dropout-year provision for earnings near the age of retirement, particularly in high-inflation environments. 
with an NRA of age sixty-five claiming on his sixty-second birthday receives 80 percent of the PIA. ${ }^{2}$ Individuals can also delay the receipt of benefits beyond the NRA and receive a delayed retirement credit (DRC). For workers reaching age sixty-five in 2000, an additional 6 percent is paid for each year of delay; this amount will steadily increase until it reaches 8 percent per year in 2008.

While a worker may claim as early as age sixty-two, receipt of SS benefits is conditioned on the earnings test until the worker reaches age sixtyfive. ${ }^{3}$ A worker age sixty-two to sixty-five may earn up to $\$ 9,600$ in 1999 without the loss of benefits, then benefits are reduced $\$ 1$ for each $\$ 2$ of earnings above this amount. Months of benefits lost through the earnings test are treated as delayed receipt, entitling the worker to a DRC on the lost benefits when he resumes full-benefit receipt.

One of the most important features of SS is that it also provides benefits to dependents of covered workers. Spouses receive a benefit equal to 50 percent of the worker's PIA, which is available once the worker has claimed benefits and the spouse has reached age sixty-two; however, the spouse only receives the larger of this and their own entitlement as a worker. ${ }^{4}$ Dependent children are also each eligible for 50 percent of the PIA, but the total family benefit cannot exceed a maximum that is roughly 175 percent of the PIA. Surviving spouses receive 100 percent of the PIA, beginning at age sixty, although there is an actuarial reduction for claiming benefits before age sixty-five or if the worker had an actuarial reduction. Finally, benefit payments are adjusted for increases in the consumer price index (CPI) after the worker has reached age sixty-two; thus, SS provides a real annuity.

\subsubsection{Labor Market Participation and Program Participation}

Table 12.1 documents the transition of men and women out of the labor force and into receipt of SS and other benefits. At ages fifty to fifty-four, 81 percent of men are working full time, 4 percent are working part time, and 15 percent are not working. The fraction of men in this age group receiving some type of benefit is about equal to the fraction not working and is divided roughly equally among those receiving DI benefits (6 percent), Unemployment Insurance (UI) benefits (5 percent), and private pensions (5 percent). ${ }^{5}$ At ages fifty-five to fifty-nine, an additional 11 percent of men

2. The reduction factor will be only five-twelfths of one percent for months beyond thirtysix months before the NRA, which is relevant for workers with an NRA past age sixty-five.

3. Until 2000, workers aged sixty-five to sixty-nine were subject to an earnings test with a higher earnings floor and lower tax rate than that for workers aged sixty-two to sixty-five. However, the Senior Citizens' Freedom to Work Act of 2000 eliminated the earnings test for persons aged sixty-five to sixty-nine as of January 2000.

4. Spousal benefits can begin earlier if there is a dependent child in the household; spousal benefits are also subject to actuarial reduction if receipt commences before the spouse's NRA.

5. In addition, 2 percent of men are receiving supplemental security income (SSI), a meanstested benefit for people who are poor and either disabled or aged sixty-five or older. 


\begin{tabular}{|c|c|c|c|c|c|}
\hline & \multicolumn{5}{|c|}{ Age } \\
\hline & $50-54$ & $55-59$ & $60-64$ & $65-69$ & $70-74$ \\
\hline \multicolumn{6}{|c|}{ Labor Market Participation } \\
\hline \multicolumn{6}{|l|}{ Men } \\
\hline Working full time & 81.2 & 69.8 & 44.6 & 14.8 & 7.1 \\
\hline Working part time & 3.5 & 5.2 & 8.3 & 10.5 & 8.3 \\
\hline Not working & 15.2 & 25.0 & 47.1 & 74.7 & 84.6 \\
\hline \multicolumn{6}{|l|}{ Women } \\
\hline Working full time & 57.4 & 48.2 & 27.5 & 8.6 & 2.6 \\
\hline Working part time & 13.6 & 12.8 & 12.1 & 10.0 & 6.5 \\
\hline Not working & 29.0 & 39.0 & 60.4 & 81.5 & 90.9 \\
\hline \multicolumn{6}{|c|}{ Program Participation } \\
\hline \multicolumn{6}{|l|}{ Men who received } \\
\hline SS retired worker benefits & 0.0 & 0.0 & 26.9 & 85.9 & 95.3 \\
\hline SS dependent spouse benefit & 0.0 & 0.0 & 0.1 & 0.1 & 0.2 \\
\hline SS survivor's benefits & 0.0 & 0.0 & 0.4 & 0.1 & 0.1 \\
\hline DI benefits & 5.7 & 9.0 & 12.9 & 0.0 & 0.0 \\
\hline SSI benefits & 2.1 & 2.7 & 3.1 & 4.0 & 4.1 \\
\hline UI benefits & 5.1 & 3.8 & 3.4 & 1.0 & 0.2 \\
\hline Private pension benefits & 4.8 & 13.2 & 27.4 & 45.2 & 48.5 \\
\hline \multicolumn{6}{|l|}{ Women who received } \\
\hline $\mathrm{SS}$ retired worker benefits & 0.0 & 0.0 & 21.3 & 57.5 & 61.3 \\
\hline SS dependent spouse benefit & 0.3 & 0.3 & 7.0 & 15.9 & 15.8 \\
\hline SS survivor's benefits & 0.6 & 1.4 & 10.6 & 14.2 & 18.3 \\
\hline DI benefits & 4.0 & 5.9 & 7.4 & 0.0 & 0.0 \\
\hline SSI benefits & 3.4 & 4.3 & 5.2 & 6.9 & 7.6 \\
\hline UI benefits & 2.7 & 2.5 & 1.6 & 0.7 & 0.3 \\
\hline Private pension benefits & 2.2 & 5.3 & 12.4 & 20.9 & 24.6 \\
\hline
\end{tabular}

Sources: Population figures are from table 14 of the 1998 Statistical Abstract of the United States (U.S. Bureau of the Census 1998) and from the Bureau of Census website (available at $\mathrm{http} / / /$ www.census.gov/population/estimates/nation/intfile2-1.txt). The SS, DI, and SSI benefit figures are from tables 5.A1 and 7.E3 of the 1998 Annual Statistical Supplement to the Social Security Bulletin (Social Security Administration 1998). Labor force participation, UI benefits, and private-pension benefits are authors' calculations from the March 1998 Current Population Survey.

leave the labor force, and there is a concurrent rise in the fraction receiving DI (to 9 percent) and private pensions (to 13 percent). At ages sixty to sixtyfour, there is a large movement out of the full-time labor market (down to 45 percent) and on to SS ( 27 percent) and private pensions ( 27 percent), and to a lesser extent, DI (13 percent). By ages sixty-five to sixty-nine, the vast majority of workers have moved out of the full-time labor market (down to 15 percent) and on to SS (86 percent) and often private pensions (45 percent). ${ }^{6}$ In short, the U.S. system features one main pathway to retirement,

6. Receipt of DI benefits goes to zero at age sixty-five, as DI recipients are automatically transferred to SS benefit receipt at age sixty-five. 
from full-time work to receipt of SS (and frequently private pension benefits), a move that typically occurs between ages sixty-two and sixty-five. This is in contrast to many other developed countries, where many people exit the labor force at earlier ages and receive UI or DI benefits prior to becoming eligible for retirement benefits. As use of these other paths to retirement is minimal in the United States, they will not factor into our analysis.

For women, the patterns are similar but with a few notable differences. First, a lower fraction of women are initially working full time at ages fifty to fifty-four (57 percent); this reflects both a higher fraction of women out of the labor force entirely ( 29 percent) and a higher fraction working part time (14 percent). Second, while many women receive SS benefits based on their own work record (58 percent of women at ages sixty-five to sixtynine), a significant fraction receive benefits only as a result of being a dependent spouse (16 percent) or widow (14 percent). Third, fewer women receive private pension benefits ( 21 percent at ages sixty-five to sixty-nine, versus 45 percent of men).

\subsubsection{Previous Related Literature}

A number of studies have used aggregate information on the labor force behavior of workers at different ages to infer the role played by SS. Hurd (1990) and Ruhm (1995) emphasize the spike in the age pattern of retirement at age sixty-two; as Hurd states, "there are no other institutional or economic reasons for the peak" (597). Using quarterly data, Blau (1994) finds that almost one-quarter of the men in the labor force at their sixtyfifth birthday retire in the next three months; this hazard rate is over 2.5 times as large as the rate in surrounding quarters. Lumsdaine and Wise (1994) examine this excess retirement at sixty-five and conclude that it cannot be explained by the change in the actuarial adjustment at this age, by the incentives in private pension plans, or by the availability of retirement health insurance through Medicare. However, SS may still play an important role by setting up the focal point of a normal retirement age.

The main body of the retirement incentives literature attempts to specifically model the role that potential SS benefits play in determining retirement. The earliest work in this area considered reduced-form models of the retirement decision as a function of SS wealth (SSW) and pension levels. Much of this literature is reviewed in Mitchell and Fields (1982); more recent cites include Diamond and Hausman (1984) and Blau (1994). While these articles differ in the estimation strategies, with the more recent work using richer models, such as nonlinear 2SLS or hazard modeling, their results generally suggest that SS's role is significant but small relative to the time trends in retirement behavior.

A key limitation of these studies is that they consider SS effects at a point in time, but not any impacts on the retirement decision arising from the time pattern of SSW accruals. This was remedied in three different ways by subsequent literatures. The first was to use structural models of retirement 
decisions by workers facing a lifetime budget constraint; for example, see Burtless (1986), Burtless and Moffitt (1984), Gustman and Steinmeier (1985, 1986), and Rust and Phelan (1997). The second was to estimate reduced-form models, but incorporate the accrual of SSW with a year of additional work; for example, see Fields and Mitchell (1984), Hausman and Wise (1985), and Sueyoshi (1989). Both of these types of studies continued to find an important, but modest, role for SS, and some indicated a larger role for private pensions. The final type of literature is the option value work of Stock and Wise noted previously. ${ }^{7}$

A final article that deserves particular mention is that of Krueger and Pischke (1992). They note that the key regressor in many of these articles, SS benefits, is a nonlinear function of past earnings and that retirement propensities are clearly correlated with past earnings. They solve this problem by using a unique natural experiment provided by the end of doubleindexing for the "notch generation" that retired in the late 1970s and early 1980s. For this cohort, SS benefits were greatly reduced relative to what they would have expected, yet the dramatic fall in labor force participation continued unabated in this era. This raises important questions about the identification of the cross-sectional literature. However, Krueger and Pischke still find significant and sizeable impacts of SS accruals on retirement, which highlights the value of the dynamic approach and suggest that the additional nonlinearities that govern the evolution of SSW (as opposed to its level) may be a fruitful source of identification for retirement models.

Each of these dynamic literatures has important limitations. The first suffers from the perhaps untenable assumptions that are required to identify these very complicated structural models. ${ }^{8}$ The second suffers from the limited way in which dynamic retirement incentives are specified. Some of these problems are remedied by the option value literature, but this literature has not separated the impact of SS incentives, as distinct from pension incentives, on retirement. ${ }^{9}$ If all dollars of retirement wealth are not weighed equally by potential retirees, either because individuals understand their firm's pension incentives better than SS incentives or because the real annuity provided by SS is valued differently than the nominal annuity provided by most defined-benefit pensions, then it is important to separately estimate SS and private pension impacts. ${ }^{10}$

In addition, all of these studies suffer from important data deficiencies, as they use data from the 1970s (when the structure of the SS system was fairly different), data from only a handful of firms, or data without com-

7. See also Samwick (1998), who uses the option value model in a reduced-form context.

8. For a criticism of this type in the context of this type of estimation of general labor supply responses, see MaCurdy (1981).

9. Stock and Wise did not attempt this decomposition, and Samwick's (1998) attempt to do so with a reduced-form version of the option value model was unsuccessful, perhaps due to the measurement error in SS incentives arising from a lack of earnings-history data.

10. The latter is suggested by Diamond and Hausman (1984), who find much smaller effects of pensions on retirement than those of SS. 
plete information on SS incentives. Finally, all of the literature suffer from a lack of careful attention to the sources of identification of the retirement incentive effects that they estimate. As highlighted by Krueger and Pischke (1992), SS benefits are a nonlinear function of earnings, making it difficult to disentangle their impact from the separate impact of earnings on the work decision. This problem is not necessarily surmounted and is potentially compounded, by the option value literature, as this measure is largely determined by wage differences across individuals and only secondarily influenced by the structure of retirement incentives. In principle, this problem can be surmounted by structural estimation of the option value model, which will identify the difference in the impacts of wages and retirement income on retirement decisions through the value of leisure parameter. But, in practice, this is only true if the particular utility structure is correct; for example, if the additional leisure of utility enters the model only as a multiplier on postretirement income and not in some other way.

To address these concerns, Coile and Gruber $(2000,2001)$ introduce a new measure, peak value, which incorporates the insights of the option value measure but focuses solely on variation in SS incentives. This is comparable to the accrual, but looks forward more than just one year: It calculates the difference between SSW at its maximum expected value and SSW at today's value in order to measure the incentive to continued work. The peak value appropriately considers the trade-off between retiring today and working to a period with much higher SSW, thereby capturing the option value of continued work even before SS entitlement ages are reached. Since wage is not included specifically into the peak value calculation, there is much more variation from the structure of the SS entitlement. ${ }^{11}$ In the empirical analysis below, both peak value and option value are used in a reduced-form context.

\subsection{Data and Empirical Strategy}

\subsubsection{Data}

Our data for this analysis comes from the HRS. ${ }^{12}$ The HRS is a survey of 12,652 individuals aged fifty-one to sixty-one in 1992 with reinterviews every two years; the first four waves of the survey $(1992,1994,1996$, and 1998) are used in this analysis. ${ }^{13}$ Spouses of respondents are also interviewed, so the total age range covered by the survey is much wider.

11. In our sample, an earnings quartic and age dummies explain only 33 percent of the variation in peak value versus 74 percent of the variation in option value.

12. The HRS is conducted by the Survey Research Center at the University of Michigan in Ann Arbor, Michigan. The data is available at http://www.umich.edu/ hrswww/. Most of the data is publicly available, although the SS and firm-level private-pension data is restricted to approved users.

13. The 1998 wave 4 data are preliminary. 
A key feature of the HRS is that it includes SS earnings histories back to 1951 for most respondents. This provides two advantages for our empirical work. First, it allows us to appropriately calculate benefit entitlements, which depend on the entire history of earnings. ${ }^{14}$ Second, it allows us to construct a large sample of person-year ${ }^{15}$ observations by using the earnings histories to compute SS retirement incentives and labor force participation at each age. We use all person-year observations age fifty-five to sixty-nine for our analysis, subject to the exclusions detailed below.

Our sample is selected conditional on working, so that we examine the incentives for retirement conditional on being in the labor force. Work is defined in one of two ways. For those person-years before 1992, when we are using earnings histories, we define work as positive earnings in two consecutive years; if earnings are positive this year, but zero the next (and if the year of zero earnings occurs at or after age fifty-five), we consider the person to have retired this year. ${ }^{16}$ For person-years from 1992 onwards, when we have the actual survey responses, we cannot use this earnings-based definition since we only have earnings at two year intervals. For this era, we use information on self-reported retirement status and dates of retirement to construct retirement measures. ${ }^{17} \mathrm{We}$ only consider individuals before their first retirement; if a person who is categorized as retired reenters the labor force, the later observations are not used.

Our sample selection criteria are as follows for men. There are 5,886 men who appear in waves 1, 2, or 3 of the HRS. ${ }^{18}$ We first exclude 1,533 men who are missing SS earnings history data. These data, fortunately, appear to be missing essentially randomly, as noted by Haider and Solon (1999). We then exclude 99 observations where the respondent or spouse was born prior to 1922, as these individuals are subject to different SS benefit rules. We also exclude 240 observations where the wife is missing SS earnings history data (necessary due to the family structure of benefits) and $67 \mathrm{ob}-$ servations with an ambiguous work history. ${ }^{19}$ Next, we exclude 730 men

14. Only earnings since 1950 are required to compute SS benefits for our sample's age range; the benefit rules specify that a shorter averaging period is used for persons born prior to 1929 .

15. "Person-years" means that an observation represents a given person in a given year, so that there are multiple observations for each person.

16. One potential problem with using earnings histories to define retirement is that an individual may move from the private sector to the state and local government sector, in which case they would be classified as retired when, in fact, they are still working. We find that results are similar when individuals who list their industry as public administration are dropped.

17. If an individual simultaneously reports their labor supply status as working and retired, we treat them as working.

18. Observations that enter the sample at wave 4 will not be used in the analysis, as multiple observations on the same person are required to establish work and retirement status.

19. Observations with missing spouse data are those for which we know that the spouse worked at least half as many years as their partner, but for which we don't have their SS earnings records. Observations with an ambiguous work history are those who have zero covered 
who retired prior to age fifty-five. The remaining 3,217 men are converted into 18,733 person-year observations by creating one observation for each year from 1980 through 1997 in which the individual is between the ages of fifty-five and sixty-nine and working at the beginning of the year. Finally, we exclude 988 person-year observations that represent labor force reentry after a previous retirement. The final sample size is 17,745 male observations. A similar process generates a sample size of 11,419 female observations.

The means of our key variables are shown in table 12.2 for men and women, respectively. In any given year, a similar percentage of the male and female sample retire, 5.7 percent for men and 5.6 percent for women. The average age of our sample is 58.5 for men and 58 for women. Some 91 percent of our male sample is married, and the typical man is 4.3 years older than his wife, while only 64 percent of our female sample is married, and the typical woman is 1.3 years younger than her husband. ${ }^{20}$ Roughly 80 percent of both samples are white. Among the male sample, 24 percent are high school dropouts, 36 percent have only a high school degree, 14 percent have some college, and 25 percent are college graduates; for women, the figures are 19 percent, 42 percent, 17 percent, and 22 percent, respectively. The average projected earnings for the next year of work are $\$ 36,152$ for men and $\$ 20,984$ for women (in 1998 dollars), and the average monthly earnings over the working life are $\$ 2,470$ for men and $\$ 1,102$ for women. The typical spouse's earnings (averaging over single people, people with nonworking spouses, and people with working spouses) are $\$ 10,813$ for an additional year of work and $\$ 612$ per month on average over the spouse's lifetime for the male sample, and $\$ 16,489$ and $\$ 1,475$ for the female sample. The typical man in our sample has forty years of labor market experience and seventeen years of tenure on their current job, and 5.4 percent of our sample is missing tenure information (indicating a short-term job); equivalent figures for women are thirty-nine and thirteen years and 6.6 percent.

\subsubsection{Incentive Variable Calculation-Accrual}

Our goal is to measure the retirement incentives inherent in the SS system. The first step in this calculation uses a simulation model we have developed to compute the PIA for any individual at all possible future retirement dates. This process is based on a careful modeling of SS benefits rules and has been cross-checked against the SS Administration's ANYPIA

earnings in the administrative data from age fifty-four through 1991, have positive selfreported earnings in 1991, and report that they have changed jobs between age fifty-four and 1991; they are excluded because it is impossible to know whether they have retired prior to 1991 and reentered the labor force.

20. The fact that a lower fraction of the female sample is married is a result of the fact that when the sample selection criteria is applied, women who are still working at age fifty-five are less likely to be married than men who are still working at age fifty-five. 
Table 12.2 Summary Statistics

\begin{tabular}{|c|c|c|}
\hline Variable & Mean & SD \\
\hline \multicolumn{3}{|c|}{ Male Sample } \\
\hline Retired & 0.057 & 0.232 \\
\hline Age & 58.5 & 3.0 \\
\hline Education; less than high school & 0.241 & 0.428 \\
\hline Education; high school & 0.363 & 0.481 \\
\hline Education; some college & 0.136 & 0.343 \\
\hline Married & 0.914 & 0.281 \\
\hline Age different with spouse & 4.3 & 4.9 \\
\hline Race; black & 0.101 & 0.301 \\
\hline Race; other nonwhite & 0.081 & 0.273 \\
\hline Earnings & 36,152 & 18,926 \\
\hline AIME & 2,470 & 945 \\
\hline Spouse's earnings & 10,813 & 14,117 \\
\hline Spouse's AIME & 612 & 654 \\
\hline Experience & 40 & 4 \\
\hline Job tenure & 17 & 12 \\
\hline Job tenure missing & 0.054 & 0.227 \\
\hline Have pension & 0.348 & 0.476 \\
\hline No. of observations & \multicolumn{2}{|c|}{17,745} \\
\hline No. of individuals & \multicolumn{2}{|c|}{3,217} \\
\hline \multicolumn{3}{|c|}{ Female Sample } \\
\hline Retired & 0.056 & 0.230 \\
\hline Age & 58.0 & 2.6 \\
\hline Education; less than high school & 0.193 & 0.395 \\
\hline Education; high school & 0.424 & 0.494 \\
\hline Education; some college & 0.168 & 0.374 \\
\hline Married & 0.640 & 0.480 \\
\hline Age different with spouse & -1.3 & 3.6 \\
\hline Race; black & 0.163 & 0.369 \\
\hline Race; other nonwhite & 0.071 & 0.257 \\
\hline Earnings & 20,984 & 14,887 \\
\hline AIME & 1,102 & 735 \\
\hline Spouse's earnings & 16,489 & 21,168 \\
\hline Spouse's AIME & 1,475 & 1,413 \\
\hline Experience & 39 & 4 \\
\hline Job tenure & 13 & 10 \\
\hline Job tenure missing & 0.066 & 0.248 \\
\hline Have pension & 0.325 & 0.468 \\
\hline No. of observations & \multicolumn{2}{|c|}{11419} \\
\hline No. of individuals & \multicolumn{2}{|c|}{2,526} \\
\hline
\end{tabular}

Note: $\mathrm{SD}=$ standard deviation .

model for accuracy. The appropriate actuarial adjustment is applied to the PIA to obtain the monthly benefit entitlement.

The next step is to compute the expected net present discounted value of SSW associated with each retirement date. Our methodology for doing so is described in Coile and Gruber (2000, 2001). For single workers, this is 
simply a sum of future benefits discounted by time preference rates and survival probabilities. For married workers, it is more complicated since we must include dependent spouse and survivor benefits and account for the joint likelihood of survival of the worker and dependent. We use a real discount rate of 3 percent and survival probabilities from the age- and sexspecific U.S. life tables from the U.S. Department of Health and Human Services (National Center for Health Statistics 1990, sec. 6).

We next compute the other SS incentive variables. We first calculate the accrual, the change in SSW resulting from an additional year of work. There are two routes through which an additional year of work affects SSW. First, the additional year of earnings will be used in the recomputation of SS benefits. For workers who have not yet worked thirty-five years, this replaces a zero in the benefits computation; for workers who have worked thirty-five years, it may replace a previous low-earnings year. So the recomputation raises SSW (or leaves it unchanged). Second, at ages sixty-two and beyond, the additional year of work implies a delay in claiming; this raises future benefits through the actuarial adjustment, but reduces the number of years of benefit receipt, so the net effect is uncertain. Both of these factors will affect workers differently, depending on their potential earnings next year, earnings history, mortality prospects (which will vary over time and cohort in our data), family structure, and spouse's earnings. Thus, the net effect of an additional year of work on SSW is theoretically ambiguous and will vary significantly across people.

Computing the accrual and other incentive variables requires projecting the worker's potential earnings next year (or in all future years). We considered a number of different projection methodologies and found that the best predictive performance was from a model which simply grew real earnings from the last observation by 1 percent per year, so we use this assumption in our simulations. ${ }^{21}$

Our SS incentive variables incorporate dependent spouse and survivor benefits, since these are important components of SSW. For a worker with a nonworking spouse, these benefits are based solely on the worker's earnings record. For a worker whose spouse is entitled to benefits on their own, the spouse's benefits are based (partially or fully) on the spouse's record, but are also included in SSW. Since a full modeling of the joint retirement decision is beyond the scope of this paper, we simply assume that spouses who are working will retire at age sixty-two; this seems reasonable, given that the median retirement age is sixty-two for women in the sample and sixty-three for men. For more evidence on joint retirement decisions, see Coile (1999).

21. Projected earnings always represent potential earnings for one full year. For example, in the case where an individual earns $\$ 2 \mathrm{X}$ in year $t$ and $\$ \mathrm{X}$ in year $t+1$ because they retire halfway through the year, the year $t+1$ observation has projected real earnings of $\$ 2 \mathrm{X}$. (1.01) and there is no $t+2$ observation (since the individual retires in year $t+1$ ). 
For the simulations below, we assume that workers claim SS benefits at retirement or when they become eligible (age sixty-two), if they have retired before then. In fact, this is not necessarily true; retirement and claiming are two distinct events, and for certain values of mortality prospects and discount rates, it is optimal to delay claiming until some time after retirement, due to the actuarial adjustment of benefits. Coile et al. (2002) investigate this issue in some detail, and they find that a relatively small share of those retiring before age sixty-two delay claiming until age sixty-three (about 10 percent) and that virtually none of those retiring at age sixty-two or later delay claiming. Given these findings, we choose not to jointly model delayed claiming here. Our incentive measures will therefore slightly overstate any subsidies to continued work, since part of this subsidy will come from delayed claiming that could be obtained without delaying retirement.

We do not incorporate private pension incentives into our analysis. Coile and Gruber (2000) estimate retirement models that include both SS and pension incentives, and they find that the results differ significantly from those for SS alone. This suggests that changes in private pension provisions may have different impacts on retirement than changes in public pensions, so that one should not extrapolate the effect of public pension reform from private pension responses. Thus, since our primary goal is to discuss the impacts of public pensions on retirement, we exclude private pensions here.

Table 12.3 shows the medians of the retirement incentive variables for our male sample by age. The median present discounted value (PDV) rises from $\$ 179,316$ at age fifty-five to a peak of $\$ 205,584$ at age sixty-five, then falls to $\$ 194,555$ at age sixty-nine. ${ }^{22}$ The age pattern of accruals demonstrates how the various effects of working an additional year enter in at different ages. From ages fifty-five to sixty-one, accruals are positive, but small, reflecting the value of the dropout year provision. From ages sixtytwo to sixty-four, accruals are two to three times larger; this is the delayedclaiming effect, whereby an additional year of work increases the actuarial adjustment and raises future benefits. ${ }^{23}$ After age sixty-five, accruals become negative and rise rapidly, as the delayed retirement credit is insufficient to compensate for the value of lost benefits.

Most importantly for our analysis, there is enormous heterogeneity in accruals, as is also shown in table 12.3. The standard deviation in accru-

22. The SSW median displayed in table 12.2 is the median SSW at age fifty-five increased or decreased each year by the median accrual. The median SSW at each age in the sample rises much more rapidly with age due to a sample selection effect (those working at later ages have higher SSW).

23. This large subsidy to work at age sixty-two is at odds with the common wisdom that the actuarial reduction at age sixty-two is approximately fair. This point is developed much further in Coile and Gruber (2000). 
The Distribution of the One-Year Accrual, Male Sample

\begin{tabular}{|c|c|c|c|c|c|c|c|c|}
\hline \multirow[b]{2}{*}{ Age } & \multirow[b]{2}{*}{$\begin{array}{l}\text { Number } \\
\text { of Obs. }\end{array}$} & \multirow[b]{2}{*}{$\begin{array}{l}\text { Median } \\
\text { SSW }\end{array}$} & \multicolumn{4}{|c|}{ Accrual } & \multirow[b]{2}{*}{$\begin{array}{c}\text { Median } \\
\text { Tax Rate }\end{array}$} & \multirow[b]{2}{*}{$\begin{array}{l}\text { Median Tax } \\
\text { Rate } 2\end{array}$} \\
\hline & & & Median & $\begin{array}{c}10 \text { th } \\
\text { Percentile }\end{array}$ & $\begin{array}{c}90 \text { th } \\
\text { Percentile }\end{array}$ & SD & & \\
\hline 55 & 2,809 & 179,316 & 2,554 & 322 & 5,492 & 2,334 & -0.072 & -0.022 \\
\hline 56 & 2,747 & 181,870 & 2,369 & 243 & 5,032 & 3,859 & -0.066 & 0.046 \\
\hline 57 & 2,444 & 184,239 & 2,128 & 167 & 4,555 & 3,382 & -0.061 & 0.060 \\
\hline 58 & 2,143 & 186,367 & 1,948 & 66 & 4,233 & 2,497 & -0.054 & 0.069 \\
\hline 59 & 1,823 & 188,315 & 1,793 & 12 & 4,136 & 3,191 & -0.048 & 0.072 \\
\hline 60 & 1,546 & 190,108 & 1,662 & 0 & 4,190 & 2,007 & -0.042 & 0.071 \\
\hline 61 & 1,255 & 191,770 & 1,670 & 0 & 4,170 & 5,113 & -0.043 & 0.064 \\
\hline 62 & 1,021 & 193,440 & 4,349 & 978 & 7,032 & 2,691 & -0.118 & -0.028 \\
\hline 63 & 716 & 197,789 & 4,511 & 430 & 7,394 & 3,532 & -0.122 & -0.005 \\
\hline 64 & 483 & 202,300 & 3,284 & 0 & 6,152 & 2,631 & -0.093 & 0.031 \\
\hline 65 & 344 & 205,584 & $(1,123)$ & $(4,741)$ & 1,785 & 4,470 & 0.027 & 0.118 \\
\hline 66 & 191 & 204,461 & $(2,301)$ & $(5,591)$ & 600 & 2,996 & 0.059 & 0.225 \\
\hline 67 & 110 & 202,160 & $(3,302)$ & $(6,773)$ & 0 & 8,027 & 0.114 & 0.269 \\
\hline 68 & 71 & 198,858 & $(4,303)$ & $(7,530)$ & 0 & 2,693 & 0.134 & 0.439 \\
\hline 69 & 42 & 194,555 & $(4,758)$ & $(7,825)$ & 0 & 2,735 & 0.119 & 0.455 \\
\hline
\end{tabular}

Notes: Tax rate 2 is from Diamond and Gruber (1999). Definitions of other variables are provided in the text. Median SSW is the age-55 median SSW incremented by the median accrual. All figures are 1998 dollars. One source of difference between the median tax rate and tax rate 2 is that tax rate 2 includes SS contributions. Adding the $12.4 \%$ payroll tax to the median tax rate results in figures very similar to tax rate $2 . \mathrm{SD}=$ standard deviation. Numbers in parentheses are negative.

als is substantial, averaging roughly $\$ 3,000$ per year. At sixty-two, for example, while there is a sizeable positive median accrual, the tenth percentile person has an accrual of only $\$ 978$ and the ninetieth percentile person has an accrual of $\$ 7,032$; the standard deviation at that age is $\$ 2,691$. It is this sizeable variation that identifies our models.

Table 12.4 shows the median retirement incentives for women by age. For women, median accruals are much smaller at all ages than they are for men, and there are no large accruals at ages sixty-two to sixty-four. In large part, this is because women have typically been less attached to the labor force over their working lives and are often dually entitled to benefits as both retired workers and as a dependent (or divorced) spouses or widows. If a woman's retired-worker benefits are less than what she is entitled to as a dependent spouse, then additional work will typically not result in a higher benefit. It is also worth noting that in the HRS, earnings histories are not available for divorced or deceased spouses; since more women than men are likely to be receiving benefits based on the record of a divorced or deceased spouse, estimates of women's incentives are likely to be subject to greater measurement error. Table 12.4 also shows that there is significant heterogeneity in women's accruals. 
The Distribution of the One-Year Accrual, Female Sample

\begin{tabular}{|c|c|c|c|c|c|c|c|}
\hline \multirow[b]{2}{*}{ Age } & \multirow[b]{2}{*}{$\begin{array}{l}\text { Number } \\
\text { of Obs. }\end{array}$} & \multirow[b]{2}{*}{$\begin{array}{l}\text { Median } \\
\text { SSW }\end{array}$} & \multicolumn{3}{|c|}{ Accrual } & \multirow[b]{2}{*}{$\mathrm{SD}$} & \multirow[b]{2}{*}{$\begin{array}{l}\text { Median Tax } \\
\text { Rate }\end{array}$} \\
\hline & & & Median & $\begin{array}{c}\text { 10th } \\
\text { Percentile }\end{array}$ & $\begin{array}{c}\text { 90th } \\
\text { Percentile }\end{array}$ & & \\
\hline 55 & 2,124 & 163,139 & 1,100 & 0 & 3,200 & 2,506 & -0.055 \\
\hline 56 & 1,954 & 164,239 & 1,176 & 0 & 3,185 & 2,503 & -0.057 \\
\hline 57 & 1,711 & 165,415 & 1,186 & 0 & 3,168 & 2,319 & -0.059 \\
\hline 58 & 1,455 & 166,601 & 1,200 & 0 & 3,138 & 2,975 & -0.061 \\
\hline 59 & 1,201 & 167,801 & 1,203 & 0 & 3,122 & 2,576 & -0.064 \\
\hline 60 & 944 & 169,004 & 1,282 & 0 & 3,119 & 2,355 & -0.065 \\
\hline 61 & 726 & 170,286 & 1,317 & 0 & 3,365 & 4,334 & -0.069 \\
\hline 62 & 547 & 171,603 & 1,360 & (586) & 5,126 & 3,732 & -0.639 \\
\hline 63 & 352 & 172,963 & 919 & $(1,264)$ & 4,647 & 3,094 & -0.045 \\
\hline 64 & 217 & 173,882 & 104 & $(1,927)$ & 4,126 & 2,597 & -0.012 \\
\hline 65 & 119 & 173,986 & $(1,534)$ & $(4,711)$ & 1,319 & 7,173 & 0.052 \\
\hline 66 & 48 & 172,452 & $(1,649)$ & $(5,031)$ & 1,251 & 5,572 & 0.062 \\
\hline 67 & 12 & 170,803 & $(2,692)$ & $(6,940)$ & 332 & 5,831 & 0.087 \\
\hline 68 & 5 & 168,111 & $(4,066)$ & $(7,998)$ & (443) & 2,780 & 0.186 \\
\hline 69 & 4 & 164,045 & $(4,178)$ & $(5,280)$ & (745) & 2,081 & 0.151 \\
\hline
\end{tabular}

Note: See table 12.3 .

\subsubsection{Incentive Variable Calculation-Forward-Looking Measures}

The recent work on retirement has highlighted an important weakness of the accrual measure. For any given year from age fifty-five to sixty-one, as we show in table 12.3, a typical worker sees a small positive accrual from additional work through the recomputation of the AIME. But, by working, that worker is also buying an option on the more-than-fair actuarial adjustment that exists from age sixty-two to sixty-four. Incorporating this option dramatically changes the nature of SS incentives, particularly at ages before age sixty-two, as documented in Coile and Gruber (2001). For a sizeable minority of workers, accrual patterns are nonmonotonic, so that forward-looking measures can deliver very different incentives than oneyear accruals.

As noted above, Stock and Wise (1990a) propose to account for these option values by contrasting the utility of retiring today versus at the optimal point in the future. Their option value model is based on the individual's indirect utility function over work and leisure

$$
V_{t}(R)=\sum_{s=t}^{R-1} p_{s \mid t} d^{s-t}\left(y_{s}\right)^{g}+\sum_{s=R}^{T} p_{s \mid t} d^{s-t}\left[k \cdot B_{s}(R)\right]^{g},
$$

where $R$ is the retirement date, $d$ is the discount rate, $p$ is the probability of being alive at some future date conditional on being alive today, $y$ is income while working, $B$ is retirement benefits, $g$ is a parameter of risk aversion, 
$k$ is a parameter to account for disutility of labor $(k \geq 1)$, and $T$ is maximum life length.

In this model, additional work has three effects. First, it raises total wage earnings, increasing utility. Second, it reduces the number of years over which benefits are received, lowering utility. Third, it may raise or lower the benefit amount, depending on the shape of the benefit function, $B(R)$. The latter two effects are weighted more heavily because of the disutility of labor, which acts as a devaluation of wage income relative to retirement income. The optimal date of retirement is the date at which the utility gained from the increase in earnings resulting from additional work is outweighed by the utility lost from the decrease in retirement income. The option value is the difference between the indirect utility from retirement at the optimal date, $R^{*}$, and the indirect utility from retirement today. As a structural estimation of the option value model is beyond the scope of this paper, we instead calculate the option value using reasonable utility parameters and include it as a regressor in a retirement model. ${ }^{24}$

As mentioned above, one possible weakness of the option value model is that much of the variation in this measure arises from differences in wages, which may not be a legitimate source of identification of retirement effects. We take two approaches to addressing this potential shortcoming. First, we include rich controls for earnings in the retirement model to capture the heterogeneity that may bias these estimates. However, since wages enter highly nonlinearly in the option value and the form of heterogeneity is unknown, even rich wage controls may not fully capture the underlying correspondence between option value and tastes for work.

Therefore, we also estimate retirement models utilizing the peak value measure. As described above, peak value is the difference between SSW at its maximum expected value and SSW at today's value. ${ }^{25}$ In this way, the peak value incorporates the insights of the option value measure and appropriately considers the trade-off between retiring today and working to a period with much higher SSW, but focuses solely on variation in SS incentives.

Table 12.5 shows the age pattern and heterogeneity for peak and option value for the male sample. The important differences between peak value and accrual, particularly at younger ages, are immediately apparent; peak values are quite large, at ages fifty-five to sixty-one, a range where accruals

24. We follow Stock and Wise in assuming values of 1.5 and 0.75 for $k$ and $g$, respectively, but we found that the fit of our model was much better with a more reasonable assumption for $d$ of 0.97 , relative to the very high discount rate of 0.75 obtained from their model. We also tested the robustness of our model to the choice of $k$ and $g$ and the results are not sensitive to this choice.

25. If the individual is at an age that is beyond the SSW optimum, then the peak value is the difference between retirement this year and next year, which is exactly the accrual rate. 
The Distribution of the Peak Value and Option Value, Male Sample

\begin{tabular}{|c|c|c|c|c|c|c|c|c|}
\hline \multirow[b]{2}{*}{ Age } & \multicolumn{4}{|c|}{ Peak Value } & \multicolumn{4}{|c|}{ Option Value } \\
\hline & Median & $\begin{array}{c}\text { 10th } \\
\text { Percentile }\end{array}$ & $\begin{array}{c}\text { 90th } \\
\text { Percentile }\end{array}$ & SD & Median & $\begin{array}{c}\text { 10th } \\
\text { Percentile }\end{array}$ & $\begin{array}{c}\text { 90th } \\
\text { Percentile }\end{array}$ & SD \\
\hline 55 & 23,579 & 4,785 & 42,312 & 16,253 & 23,755 & 4,956 & 37,331 & 11,461 \\
\hline 56 & 21,266 & 4,276 & 39,893 & 15,790 & 22,030 & 4,728 & 35,302 & 10,780 \\
\hline 57 & 18,548 & 3,929 & 37,021 & 14,386 & 20,207 & 4,134 & 32,641 & 10,119 \\
\hline 58 & 16,804 & 3,630 & 34,450 & 13,865 & 18,390 & 3,258 & 30,507 & 9,512 \\
\hline 59 & 15,456 & 3,105 & 31,339 & 13,398 & 16,894 & 2,879 & 28,240 & 8,861 \\
\hline 60 & 14,083 & 2,479 & 28,931 & 12,559 & 15,225 & 2,041 & 25,728 & 8,217 \\
\hline 61 & 12,925 & 2,059 & 24,597 & 12,320 & 13,623 & 1,775 & 23,146 & 7,477 \\
\hline 62 & 11,886 & 1,769 & 21,665 & 10,363 & 11,877 & 1,442 & 20,767 & 6,649 \\
\hline 63 & 8,102 & 762 & 15,267 & 9,707 & 10,143 & 1,257 & 18,164 & 5,913 \\
\hline 64 & 3,508 & 0 & 8,805 & 7,954 & 8,057 & 452 & 15,343 & 5,113 \\
\hline 65 & $(1,042)$ & $(4,692)$ & 4,908 & 9,099 & 6,187 & 0 & 12,606 & 4,396 \\
\hline 66 & $(2,250)$ & $(5,591)$ & 1,520 & 7,556 & 4,342 & 0 & 9,850 & 3,612 \\
\hline 67 & $(3,302)$ & $(6,773)$ & 0 & 9,033 & 2,690 & 0 & 7,662 & 3,048 \\
\hline 68 & $(4,303)$ & $(7,530)$ & 0 & 2,871 & 1,962 & 0 & 5,151 & 1,937 \\
\hline 69 & $(4,758)$ & $(7,825)$ & 0 & 2,735 & 893 & 0 & 2,616 & 963 \\
\hline
\end{tabular}

Notes: Peak value is in 1998 dollars; option value is in utility units. SD = standard deviations. Numbers in parentheses are negative.

are small. ${ }^{26}$ The peak value declines sharply with age, as people move closer to or reach their optimal retirement date; the declines occur at a fairly constant rate up until about age sixty-two, then become very large. The peak value is positive for the median person until they reach age sixty-five, and then it becomes negative. As with the accrual, there is an enormous amount of heterogeneity in all of these measures that can be used to identify our models. Part of this variance arises from heterogeneity in the peak year. For 38 percent of our sample, age sixty-five is the peak; for 11 percent, it is age seventy, and there are substantial masses at ages sixty-six, sixtyseven, sixty-eight, and sixty-nine. Partly, this reflects the evolving generosity of the DRC over time; the peak occurs after age sixty-five for 28 percent of the workers in the oldest cohorts in our sample versus 73 percent of the workers in the youngest cohorts.

Although option value is measured in utility units and cannot be directly compared to peak value, option value follows the same declining pattern

26. Note that we take the median of each variable, so that all the numbers in any given row do not necessarily represent the incentives facing a single person. This explains a seeming inconsistency between tables 12.3 and 12.5 , which is that the accruals from age fifty-five through age sixty-four add up to more than the peak value at age fifty-five, despite the fact that age sixty-five is often the peak for SSW. As we show in Coile and Gruber (2001), this is a fallacy of composition, and for any given individual the peak value is just the sum of accruals to the peak SSW age. 
The Distribution of the Peak Value and Option Value, Female Sample

\begin{tabular}{|c|c|c|c|c|c|c|c|c|}
\hline \multirow[b]{2}{*}{ Age } & \multicolumn{4}{|c|}{ Peak Value } & \multicolumn{4}{|c|}{ Option Value } \\
\hline & Median & $\begin{array}{c}10 \text { th } \\
\text { Percentile }\end{array}$ & $\begin{array}{c}\text { 90th } \\
\text { Percentile }\end{array}$ & SD & Median & $\begin{array}{c}\text { 10th } \\
\text { Percentile }\end{array}$ & $\begin{array}{c}\text { 90th } \\
\text { Percentile }\end{array}$ & SD \\
\hline 55 & 9,359 & 166 & 33,369 & 14,639 & 12,506 & 1,174 & 27,876 & 10,113 \\
\hline 56 & 8,981 & 134 & 32,237 & 14,144 & 12,195 & 953 & 26,443 & 9,599 \\
\hline 57 & 8,097 & 120 & 30,074 & 13,791 & 11,309 & 794 & 24,471 & 8,952 \\
\hline 58 & 6,799 & 90 & 28,006 & 13,325 & 10,235 & 574 & 22,223 & 8,311 \\
\hline 59 & 5,724 & 78 & 24,602 & 12,323 & 9,334 & 369 & 20,350 & 7,649 \\
\hline 60 & 4,889 & 70 & 21,578 & 11,991 & 8,705 & 338 & 18,780 & 7,046 \\
\hline 61 & 3,685 & 39 & 19,680 & 12,077 & 7,584 & 131 & 16,594 & 6,352 \\
\hline 62 & 2,121 & (553) & 17,115 & 9,432 & 6,447 & 130 & 14,218 & 5,460 \\
\hline 63 & 1,424 & $(1,264)$ & 12,171 & 8,539 & 5,514 & 88 & 12,292 & 4,778 \\
\hline 64 & 280 & $(1,927)$ & 7,806 & 7,574 & 4,382 & 0 & 10,169 & 4,040 \\
\hline 65 & $(1,534)$ & $(4,711)$ & 3,880 & 9,901 & 3,496 & 0 & 8,995 & 3,535 \\
\hline 66 & $(1,601)$ & $(5,031)$ & 3,651 & 7,387 & 2,504 & 0 & 7,761 & 2,761 \\
\hline 67 & $(2,692)$ & $(6,940)$ & 332 & 6,362 & 2,281 & 0 & 5,800 & 2,194 \\
\hline 68 & $(4,066)$ & $(7,998)$ & (443) & 2,780 & 1,417 & 130 & 4,796 & 1,804 \\
\hline 69 & $(4,178)$ & $(5,280)$ & $(745)$ & 2,081 & 274 & 0 & 706 & 340 \\
\hline
\end{tabular}

Note: See table 12.5 .

as peak value. The median option value falls monotonically with age, but remains positive even beyond age sixty-five, as additional earnings offset losses in SSW. There is also substantial heterogeneity in the option value measure.

Table 12.6 shows the distribution of the peak value and option value measures by age for the female sample. The age trends are largely similar to those for men, although the dollar amounts are smaller since women typically benefit less from additional work for reasons described previously and also have lower earnings, which lowers the option value.

\subsection{Empirical Framework and Results}

\subsubsection{Regression Framework}

In a standard retirement model, SS will play two roles in the decision regarding whether to retire this year or to continue working. The first is through wealth effects: higher SSW will induce individuals to consume more of all goods, including leisure, and to retire earlier. The second is through accrual effects: the individual's decision to continue to work is a function of the increase in retirement consumption resulting from additional work.

Following this discussion, we use the incentive variables described above to run regressions of the form 


$$
\begin{aligned}
R_{i t}= & b_{0}+b_{1} \mathrm{SSW}_{i t}+b_{2} \mathrm{INCENT}_{i t}+b_{3} X_{i t}+b_{4} \mathrm{AGE}_{i t}+b_{5} \mathrm{EARN}_{i t} \\
& +b_{6} \mathrm{AIME}_{i t}+b_{7} \mathrm{MAR}_{i t}+b_{8} \mathrm{AGEDIFF}_{i}+b_{9} \mathrm{SPEARN}_{i t} \\
& +b_{10} \mathrm{SPAIME}_{i t}+b_{11} Y_{t}+e,
\end{aligned}
$$

where SSW is the expected PDV of SS benefits that is available to the person if he retires that year $(t)$; INCENT is one of the incentive measures noted above (accrual, option value, and peak value); $\mathbf{X}$ is a vector of control variables that may importantly influence the retirement decision, but do not enter directly into the calculation of SSW (education, race, veteran status, born in the United States, region of residence, experience in the labor market and its square, ${ }^{27}$ tenure at the firm and its square, thirteen major industry dummies, and seventeen major occupation dummies); AGE is either entered linearly or as a set of dummies for each age fifty-five to sixtynine; EARN is a control for potential earnings in the next year; AIME is a control for average monthly lifetime earnings as of period $t:{ }^{28}$ MAR is a dummy for marital status; AGEDIFF controls for the age difference with the spouse; SPEARN and SPAIME are the spouse's next year and average lifetime earnings; and $Y$ is a series of year dummies. Since our dependent variable is dichotomous, we estimate the model as a probit. We have also estimated these models as Cox proportional hazard models and the results were very similar; this is not surprising, given that the models all include a full set of age dummies that pick up the same factors captured by the baseline in the hazard model.

This model parallels the types of models used in the first round of research on SS and retirement, with one important exception: the earnings controls. Most articles in this literature did not control for earnings, and no articles controlled for both earnings around time of retirement and average lifetime earnings. Yet both of these variables are clearly important determinants of both SS incentives and retirement decisions, so excluding them from the model imparts a potential omitted variables bias. Moreover, there is no reason to suspect that heterogeneity is a purely linear function of earnings. Thus, for each of the earnings controls previously listed, we include squared, cubed, and quartic terms as well. Moreover, it is possible that heterogeneity in retirement is also related to the relationship between current and average lifetime earnings; we therefore also include a full set of interactions between the EARN and AIME quartics in order to reflect this.

Finally, it is important to highlight that our work is focused on the im-

27. Experience is defined as age minus years of education minus six, since the HRS selfreported earnings histories may have gaps and administrative data do not include employment in noncovered sectors.

28. Note that AIME is time varying because additional years of work change average lifetime earnings through the dropout-year provision. 
pact of SS on the labor force participation decision. A separate and interesting issue is the impact of SS on the marginal labor supply decision among those participating in the labor force. This is more complicated for those around retirement age, since it involves incorporating the role of the earnings test, which we avoid with our analysis of participation. This, in turn, would involve modeling expectations about the earnings test, since individuals appear not to understand that this is just a benefits delay instead of a benefits cut. This is clearly a fruitful avenue for further research.

\subsubsection{Social Security Incentives and Retirement}

Table 12.7 shows the results of estimating equation (2) for men for the three incentive measures and the two possible sets of age controls. Peak value, accrual, and SSW are expressed in $\$ 100,000$; option value is expressed in units of 10,000. The magnitude of the coefficients is illustrated by the term in square brackets, which gives the implied percentage-point impact of a $\$ 1,000$ increase in the accrual/peak value and a $\$ 10,000$ increase in SSW.

In all the models, we estimate a positive impact of SSW levels, as expected; however, the coefficient is significant at the 5 percent level in only two of the six models. The coefficient implies that each $\$ 10,000$ increase in SSW increases the probability of retirement by about 0.2 percent, or about 3.5 percent of the sample average retirement rate; evaluated at the mean, this corresponds to an elasticity of nonparticipation with respect to benefits of 0.60 . The coefficients are about 50 percent greater in the models with linear age than in those with age dummies.

The coefficient on the accrual is the wrong sign (positive) and is highly insignificant once age dummies are included in the model. This suggests that there is little impact of one-year-forward incentives on retirement decisions. This could reflect the fact that individuals are not at all forwardlooking in their decisions. Alternatively, given nonlinearities in future accruals, it could represent the fact that individuals are not considering solely the accrual to the next year but the entire future path of incentives.

This possibility is addressed in the next two sets of columns, which show the estimates from the peak value and option value models. In both cases, we now estimate significant negative impacts of the forward-looking incentive measures for retirement decisions. We find that each $\$ 1,000$ in peak value lowers the odds of retirement by 0.05 percent, or about 1 percent of the sample average retirement rate; this corresponds to an elasticity of nonparticipation with respect to benefits of 0.15 . For option value, it is not possible to calculate the impact of a simple $\$ 1,000$ increment since this is a utility-based metric; we will return to comparisons of these two models in the simulation section below.

The coefficients on peak value and option value are similar whether age 


\begin{tabular}{|c|c|c|c|c|c|c|}
\hline \multirow[b]{3}{*}{ Variable } & \multicolumn{6}{|c|}{ Specification } \\
\hline & \multicolumn{2}{|c|}{ Accrual } & \multicolumn{2}{|c|}{ Peak Value } & \multicolumn{2}{|c|}{ Option Value } \\
\hline & (1) & (2) & (3) & (4) & (5) & (6) \\
\hline \multirow[t]{2}{*}{ SSW } & 0.3581 & 0.2190 & 0.2519 & 0.1718 & 0.1730 & 0.1075 \\
\hline & $(0.1163)$ & $(0.1162)$ & (0.1157) & $(0.1170)$ & $(0.1146)$ & $(0.1173)$ \\
\hline$\$ 10,000$ change $^{a}$ & {$[0.0030]$} & [0.0018] & {$[0.0021]$} & {$[0.0014]$} & {$[0.0015]$} & {$[0.0009]$} \\
\hline \multirow[t]{2}{*}{ Incentive measure } & 1.8360 & 0.4560 & -0.4289 & -0.5697 & -0.2368 & -0.2106 \\
\hline & $(0.3648)$ & $(0.4137)$ & $(0.2238)$ & $(0.2367)$ & $(0.0539)$ & $(0.0522)$ \\
\hline$\$ 1,000$ change $^{\mathrm{b}}$ & {$[0.0015]$} & [0.0004] & {$[-0.0004]$} & {$[-0.0005]$} & & \\
\hline \multirow[t]{2}{*}{ Age } & 0.0922 & & 0.0877 & & 0.0691 & \\
\hline & $(0.0154)$ & & $(0.0155)$ & & $(0.0162)$ & \\
\hline \multirow[t]{2}{*}{ Age 56} & & -0.0311 & & -0.0332 & & -0.0470 \\
\hline & & $(0.0706)$ & & $(0.0707)$ & & $(0.0711)$ \\
\hline \multirow[t]{2}{*}{ Age 57} & & -0.0693 & & -0.0759 & & -0.1075 \\
\hline & & $(0.0808)$ & & $(0.0810)$ & & $(0.0816)$ \\
\hline \multirow[t]{2}{*}{ Age 58} & & 0.0587 & & 0.0479 & & 0.0009 \\
\hline & & $(0.0877)$ & & $(0.0878)$ & & $(0.0890)$ \\
\hline \multirow[t]{2}{*}{ Age 59} & & 0.0696 & & 0.0579 & & -0.0065 \\
\hline & & $(0.0986)$ & & $(0.0989)$ & & $(0.1006)$ \\
\hline \multirow[t]{2}{*}{ Age60 } & & 0.2079 & & 0.1932 & & 0.1082 \\
\hline & & $(0.1088)$ & & $(0.1092)$ & & $(0.1117)$ \\
\hline \multirow[t]{2}{*}{ Age61 } & & 0.3032 & & 0.2847 & & 0.1794 \\
\hline & & $(0.1178)$ & & $(0.1179)$ & & $(0.1215)$ \\
\hline \multirow[t]{2}{*}{ Age62 } & & 0.8999 & & 0.8897 & & 0.7650 \\
\hline & & $(0.1279)$ & & $(0.1268)$ & & $(0.1321)$ \\
\hline \multirow[t]{2}{*}{ Age63 } & & 0.8122 & & 0.7852 & & 0.6512 \\
\hline & & $(0.1446)$ & & $(0.1439)$ & & $(0.1495)$ \\
\hline \multirow[t]{2}{*}{ Age64 } & & 0.6908 & & 0.6424 & & 0.5050 \\
\hline & & $(0.1622)$ & & $(0.1628)$ & & $(0.1682)$ \\
\hline \multirow[t]{2}{*}{ Age65 } & & 1.0796 & & 0.9881 & & 0.8534 \\
\hline & & $(0.1779)$ & & $(0.1819)$ & & $(0.1870)$ \\
\hline \multirow[t]{2}{*}{ Age66 } & & 0.5924 & & 0.4928 & & 0.3540 \\
\hline & & $(0.2062)$ & & $(0.2097)$ & & $(0.2146)$ \\
\hline \multirow[t]{2}{*}{ Age67 } & & 0.4542 & & 0.3467 & & 0.1953 \\
\hline & & $(0.2539)$ & & $(0.2578)$ & & $(0.2615)$ \\
\hline \multirow[t]{2}{*}{ Age68 } & & 0.7229 & & 0.5974 & & 0.4231 \\
\hline & & $(0.2387)$ & & $(0.2429)$ & & $(0.2483)$ \\
\hline Pseudo $R^{2}$ & 0.1215 & 0.1379 & 0.1198 & 0.1386 & 0.1223 & 0.1402 \\
\hline
\end{tabular}

Notes: All regressions include controls for education, race, experience, marital status, industry, occupation, region, year, as well as a quartic in earnings, a quartic in lifetime earnings, and the interactions of these quartics (plus same earnings variables for the spouse). Standard deviations in parentheses. Magnitude of coefficients is in square brackets.

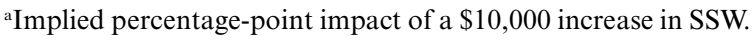

${ }^{b}$ Implied percentage-point impact of a $\$ 1,000$ increase in SSW. 
is controlled for using a linear variable or age dummies. The goodness of fit of all six models is similar, with a pseudo $R^{2}$ of about 12 percent in models without age dummies and 14 percent in models with age dummies. These findings suggest that the forward-looking models of the type advocated by Stock and Wise are very important for explaining retirement behavior. Individuals do appear to recognize the future path of SSW accumulation, and they take this into account in making their retirement decisions.

The other variables in the regression have their expected impacts. ${ }^{29}$ There is a rising pattern of retirement propensities with age, with particularly large effects at ages sixty-two, sixty-three, sixty-five, and sixty-nine. Figure 12.2 displays the empirical retirement hazard for the sample and the age dummies estimated in the three models. The age dummies in the accrual and peak value models are nearly identical to the empirical hazard, indicating that these models explain little of the variation across ages in retirement propensities; on the other hand, the age dummies in the option value model are significantly below the empirical hazard.

Being married and having a larger age difference with one's wife decrease the probability of retirement, although only the former is significant. More experience lowers the odds of retirement, conditional on age, but this relationship is decreasing in absolute value. There is no distinct relationship with tenure, although there is a very significant positive impact of being in the 6 percent of the sample with missing tenure data; this is consistent with lower labor force attachment among those in jobs of short duration. The industry and occupation dummies do not show a particularly strong pattern, with the exception of higher retirement rates in the armed forces and the cleaning- and building-services occupations. There is no significant time pattern to retirement behavior, which is consistent with Quinn (1999) who shows that the strong time series trend towards earlier retirement was arrested beginning in the mid-1980s. There is no strong regional pattern, other than a higher retirement rate in the western region and a lower rate in New England. ${ }^{30}$

The retirement probits for the female sample are shown in table 12.8. The SSW coefficients are roughly the same size as in the men's probits and are significant in the accrual and peak value models. As in the men's probits, the coefficients on accrual are positive and highly insignificant. Surprisingly, the results using the forward-looking incentive variables are mixed: The coefficients on peak value are negative, but small and insignificant, while the coefficients on option value are negative and significant. One possible explanation for the insignificant coefficients is the measurement error in women's incentive variables due to a lack of earnings histories for

29. Only coefficients on age or age dummies are shown in table 12.7.

30. See Coile and Gruber (2000) for a discussion of results incorporating pensions in the retirement incentive variables and including health status and health insurance as regressors. 


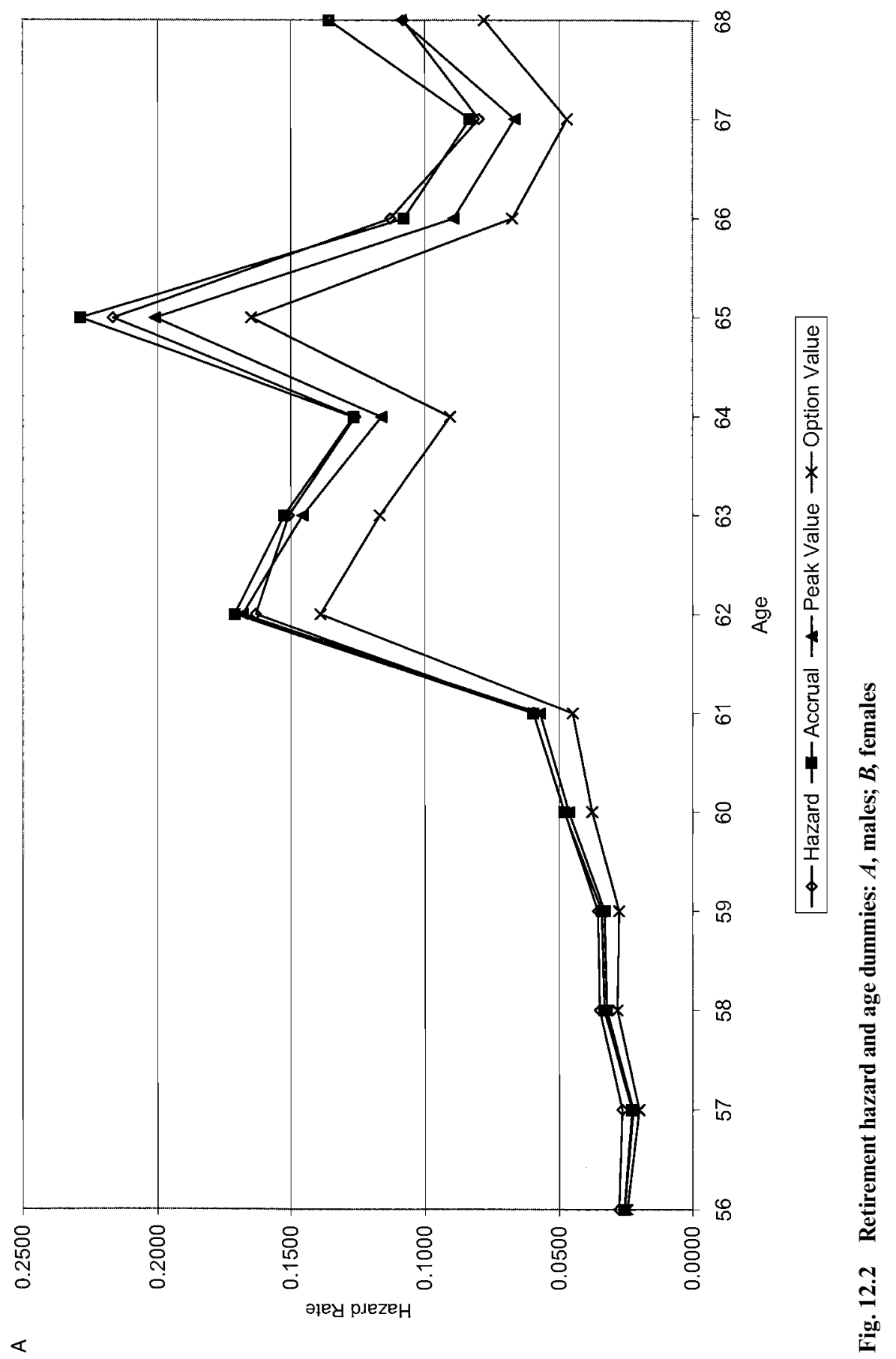




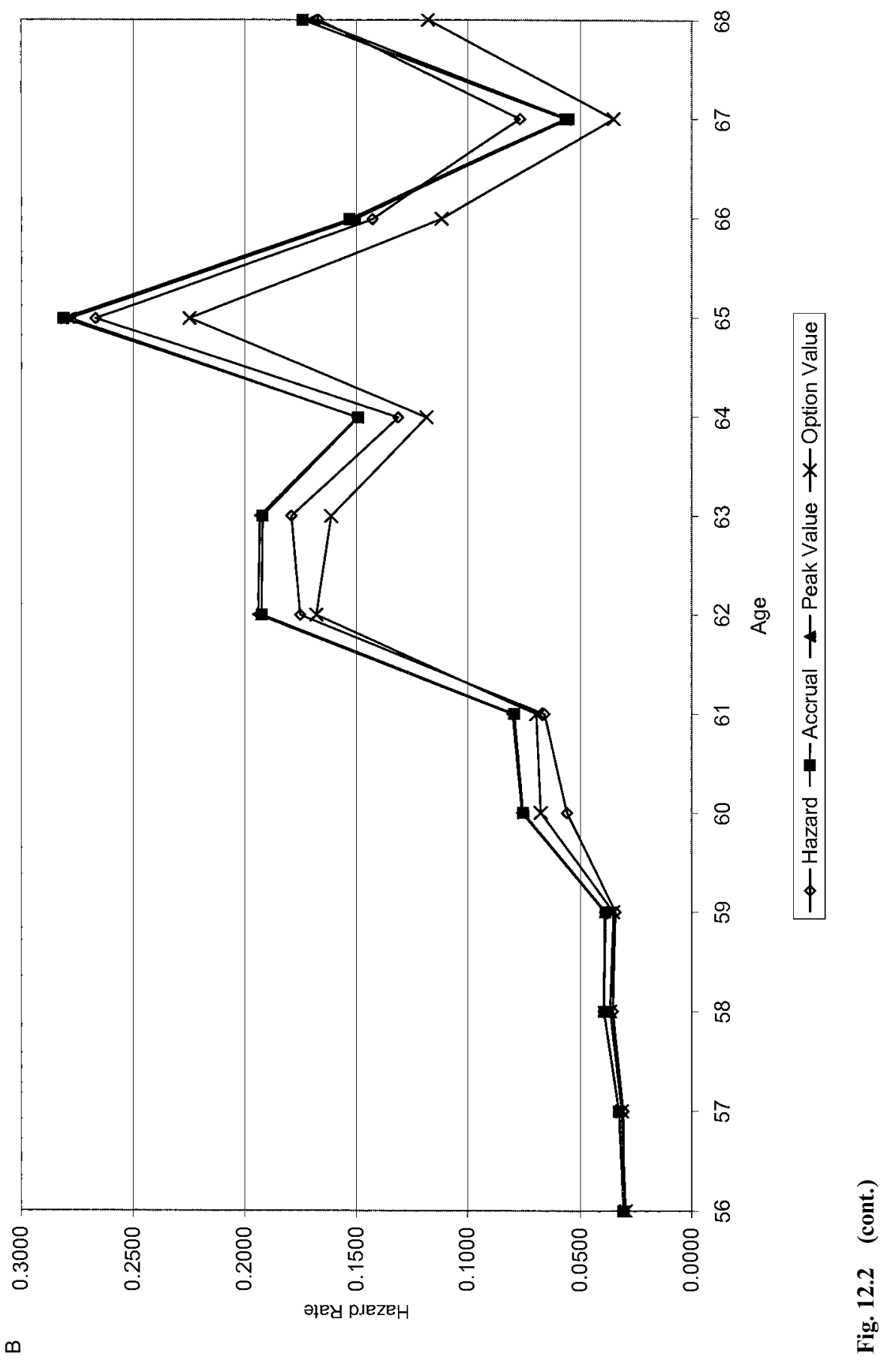


Table 12.8

Retirement Probits, Female Sample

\begin{tabular}{|c|c|c|c|c|c|c|}
\hline \multirow[b]{3}{*}{ Variable } & \multicolumn{6}{|c|}{ Specification } \\
\hline & \multicolumn{2}{|c|}{ Accrual } & \multicolumn{2}{|c|}{ Peak Value } & \multicolumn{2}{|c|}{ Option Value } \\
\hline & (1) & (2) & (3) & (4) & (5) & (6) \\
\hline \multirow[t]{2}{*}{ SSW } & 0.2619 & 0.2265 & 0.2430 & 0.2169 & 0.2080 & 0.1838 \\
\hline & $(0.1132)$ & $(0.1130)$ & $(0.1132)$ & $(0.1129)$ & $(0.1142)$ & $(0.1135)$ \\
\hline$\$ 10,000$ change $e^{a}$ & {$[0.0020]$} & {$[0.0017]$} & {$[0.0019]$} & [0.0017] & {$[0.0016]$} & {$[0.0014]$} \\
\hline \multirow[t]{2}{*}{ Incentive measure } & 0.7727 & 0.4773 & -0.0618 & -0.0132 & -0.2695 & -0.2414 \\
\hline & $(0.7291)$ & $(0.8169)$ & $(0.0253)$ & $(0.2856)$ & $(0.0772)$ & $(0.0752)$ \\
\hline$\$ 1,000$ change $^{b}$ & {$[0.0006]$} & [0.0004] & $-[0.00005]$ & {$[-0.00001]$} & & \\
\hline \multirow[t]{2}{*}{ Age } & 0.1219 & & 0.1217 & & 0.1040 & \\
\hline & $(0.0219)$ & & $(0.0219)$ & & $(0.0223)$ & \\
\hline \multirow[t]{2}{*}{ Age56 } & & 0.0223 & & 0.0217 & & 0.0101 \\
\hline & & $(0.0825)$ & & $(0.0824)$ & & $(0.0826)$ \\
\hline \multirow[t]{2}{*}{ Age 57} & & 0.0474 & & 0.0480 & & 0.0312 \\
\hline & & $(0.0960)$ & & $(0.0959)$ & & $(0.0961)$ \\
\hline \multirow[t]{2}{*}{ Age 58} & & 0.1254 & & 0.1268 & & 0.0964 \\
\hline & & (0.1104) & & $(0.1103)$ & & $(0.1104)$ \\
\hline \multirow[t]{2}{*}{ Age59 } & & 0.1186 & & 0.1212 & & 0.0784 \\
\hline & & $(0.1295)$ & & $(0.1294)$ & & $(0.1298)$ \\
\hline \multirow[t]{2}{*}{ Age60 } & & 0.4364 & & 0.4389 & & 0.3811 \\
\hline & & $(0.1415)$ & & $(0.1414)$ & & $(0.1422)$ \\
\hline \multirow[t]{2}{*}{ Age61 } & & 0.4587 & & 0.4632 & & 0.3928 \\
\hline & & $(0.1585)$ & & $(0.1584)$ & & $(0.1599)$ \\
\hline \multirow[t]{2}{*}{ Age62 } & & 1.0015 & & 1.0075 & & 0.9102 \\
\hline & & $(0.1702)$ & & $(0.1699)$ & & $(0.1720)$ \\
\hline \multirow[t]{2}{*}{ Age63 } & & 0.9872 & & 0.9918 & & 0.8721 \\
\hline & & $(0.1939)$ & & $(0.1937)$ & & $(0.1966)$ \\
\hline \multirow[t]{2}{*}{ Age64 } & & 0.8106 & & 0.8119 & & 0.6718 \\
\hline & & $(0.2229)$ & & $(0.2223)$ & & $(0.2262)$ \\
\hline \multirow[t]{2}{*}{ Age65 } & & 1.2619 & & 1.2533 & & 1.0901 \\
\hline & & $(0.2464)$ & & $(0.2456)$ & & $(0.2497)$ \\
\hline \multirow[t]{2}{*}{ Age66 } & & 0.8181 & & 0.8086 & & 0.6318 \\
\hline & & $(0.3377)$ & & $(0.3371)$ & & $(0.3406)$ \\
\hline \multirow[t]{2}{*}{ Age67 } & & 0.2807 & & 0.2714 & & 0.0774 \\
\hline & & $(0.5925)$ & & $(0.5941)$ & & (0.6078) \\
\hline \multirow[t]{2}{*}{ Age68 } & & 0.8993 & & 0.8815 & & 0.6609 \\
\hline & & $(0.5079)$ & & $(0.5084)$ & & $(0.5215)$ \\
\hline Pseudo $R^{2}$ & 0.1418 & 0.1530 & 0.1416 & 0.1530 & 0.1441 & 0.1549 \\
\hline
\end{tabular}

Note: See table 12.7.

divorced and deceased spouses; however, this would not explain why option value is significant. ${ }^{31}$ The linear age variable and age dummies are sim-

31. Coile (2003) estimates similar models and finds that women respond to both peak value and option value measures. Her sample differs in two ways from the female sample here: First, she looks only at married women (who may have less measurement error in their incentive variables than unmarried women) and second, she conditions on working at age fifty or later (versus fifty-five here). 
ilar to those in the men's model, and again the age dummies from the option value model are below the empirical hazard (figure 12.2, panel B). The pseudo $R^{2}$ is about 15 percent in all six models.

In summary, SSW has a positive and marginally significant effect on retirement behavior for both men and women. The one-year accrual has the wrong sign and an insignificant effect, while the forward-looking incentive measures, peak value and option value, have a significant negative effect (although peak value is not significant for women). However, the implications of the estimates that we have presented thus far are difficult to interpret in a vacuum; are $\$ 1,000$ changes in peak value considered large or small? To provide some more context for the magnitudes of our results, we conduct simulations of changes to the SS system in the following section.

\subsection{Policy Simulations}

In this section, we consider two potential major reforms to the SS system. The first policy change examined is to raise both the early retirement age (ERA) and the normal retirement age (NRA) by three years, to sixtyfive and sixty-eight, respectively. The second policy change is to move from the current SS system to a common system simulated by all chapters in this volume: an ERA of sixty and NRA of sixty-five, a replacement rate of 60 percent of AIME at age sixty-five, and a 6 percent annual actuarialadjustment factor between ages sixty and seventy.

Our basic procedure is to reestimate the incentive variables under the new policy, then use the probit estimates discussed above to predict changes in retirement behavior. But executing these simulations raises the difficult question of how to translate the earlier models into policy responses. In particular, we face the difficulty that our models are largely unable to explain the age pattern of retirement, an age pattern that is certainly at least partly due to SS incentives (in particular the spike at age sixty-two).

We therefore consider three possible simulation approaches. In the first simulation (S1), we use the model with linear age. This simulation does not allow for any age-specific deviations from a linear baseline, therefore increasing the explanatory power of our financial incentive variables. In the second simulation (S2), we use the model with age dummies, but we only consider the impact of changing the financial incentive variables; that is, when retirement ages change, we only consider the impact that this has through changing peak or option value, and not through any other structural shifts. In contrast, the third simulated approach (S3) is also based on the model in which age dummies are used, but imposes a shift in the spikes of the retirement hazard when the policy is changed; that is, when retirement ages change, we assume that there is a corresponding change in the 
Table 12.9 Average Retirement Rates in Simulations

\begin{tabular}{lcc}
\hline & \multicolumn{2}{c}{ Simulated Reform } \\
\cline { 2 - 3 } Case & Plus 3 Years & Common \\
\hline & Males & \\
Base retirement rate & 0.057 & 0.057 \\
Peak value & 0.048 & 0.080 \\
S1 & 0.051 & 0.064 \\
S2 & 0.037 & 0.076 \\
S3 & 0.048 & \\
Option value & 0.051 & 0.081 \\
S1 & 0.039 & 0.071 \\
S2 & 0.083 \\
S3 & 0.066 & \\
& & 0.066 \\
Base retirement rate & 0.057 & 0.094 \\
Option value & 0.056 & 0.088 \\
S1 & 0.039 & 0.100 \\
S2 & & \\
S3 & & \\
\hline
\end{tabular}

underlying hazard of retirement by age. ${ }^{32}$ Simply put, S2 corresponds to the assumption that any age pattern not captured by our financial measures is not due to retirement programs; $\mathrm{S} 3$ assumes that the entire age pattern is driven by retirement programs. Since it is unknown whether or not the policy changes would move the spikes in the retirement hazard, S2 and S3 can be thought of as bounding the true effect of the policy change, with S1 somewhere in between.

We present our findings in two formats. Table 12.9 shows the baseline average retirement rate as well as the average retirement rates in the various policy simulations..$^{33}$ The second format is graphical. Each of the figures 12.3-12.11 shows the impact on the hazard of retirement and the cumulative probability of being in the labor force for the baseline and for each of the two reforms. The different figures correspond to different models and simulations: Figures 12.3-12.5 are for the peak value model for males for

32. For the first policy, all age dummies are incremented by three years, so that the retirement hazard at age sixty-two is moved to age sixty-five, and so forth. For the second policy, the age-sixty-two dummy is moved to age sixty, the dummies before age sixty and at ages sixtyfive and older are unaffected, and the age dummies at ages sixty-one to sixty-four are replaced with an average of the age-sixty-three and -sixty-four dummies. Admittedly, these are ad hoc adjustments, but it is difficult to predict how these policy changes would affect the underlying propensity to retire at various ages.

33. Accrual is not used in the simulations, as the coefficients are the wrong sign and insignificant. Peak value is not used in the simulations for women, as the coefficients are highly insignificant. 
A

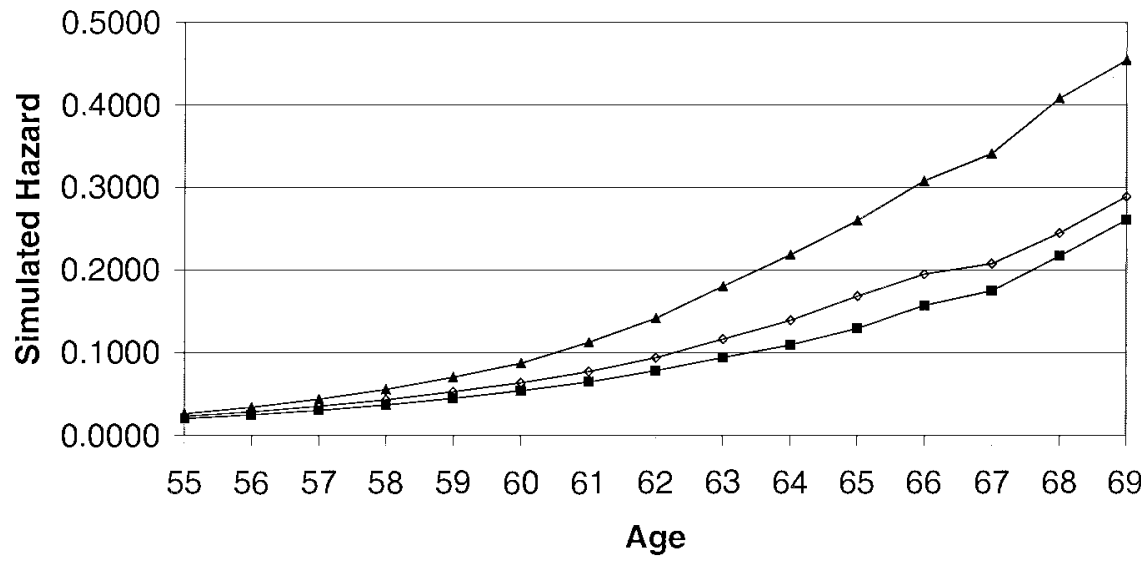

$\rightarrow$ Baseline Hazard $\rightarrow-$ Plus 3 Years $-₫$ Common Reform

B

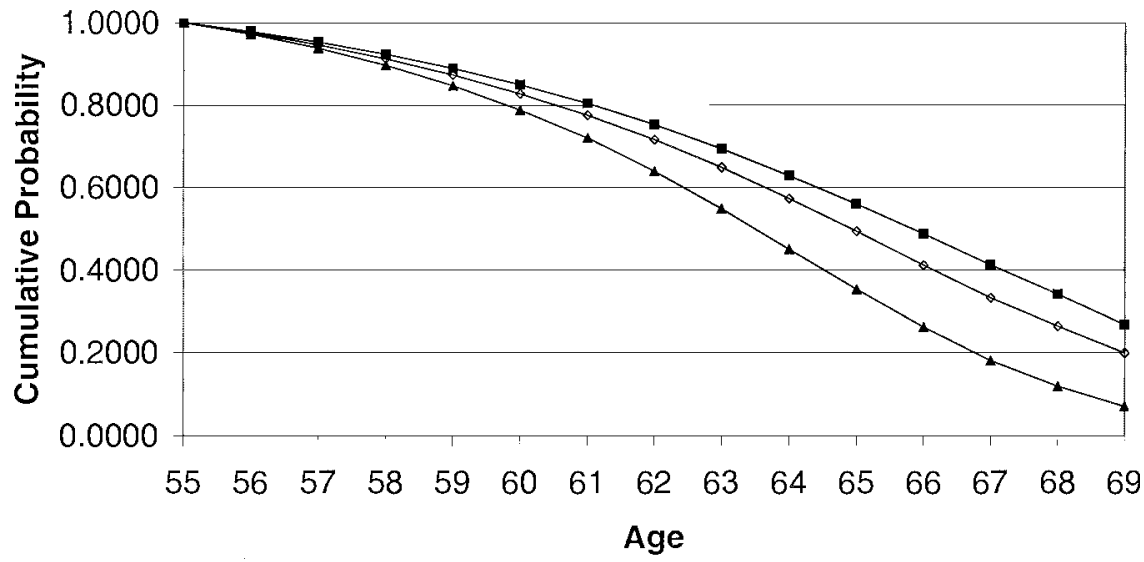

$\rightarrow$ Baseline CDF $\rightarrow$ Plus 3 Years $\rightarrow$ Common Reform

Fig. 12.3 S1 for males, peak value model: $A$, simulated hazard; $B$, cumulative probability

simulations $\mathrm{S} 1, \mathrm{~S} 2$, and $\mathrm{S} 3$; figures $12.6-12.8$ are for the option value model for males; and figures 12.9-12.11 are for the option value model for females.

\subsubsection{Raising the ERA and NRA by Three Years}

The first policy change, raising the ERA and NRA, would have the effect of lowering the average retirement rate for both men and women. The reduction is 1 percentage point or less in S1 and S2, but 2-3 percentage 
A

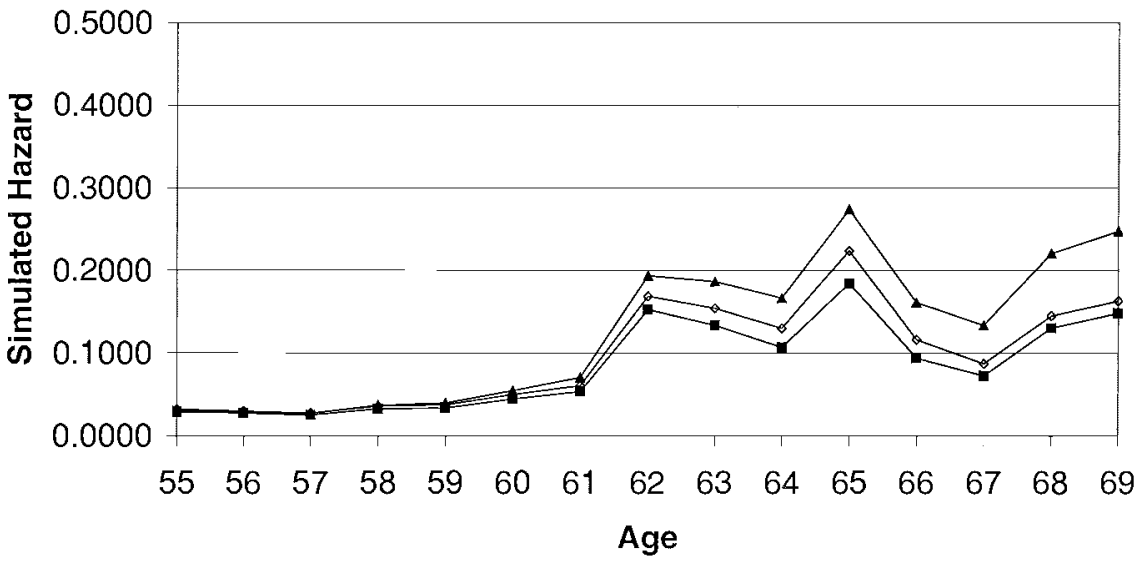

$\rightarrow$ Baseline Hazard $\rightarrow$ Plus 3 Years $\star$ Common Reform

B

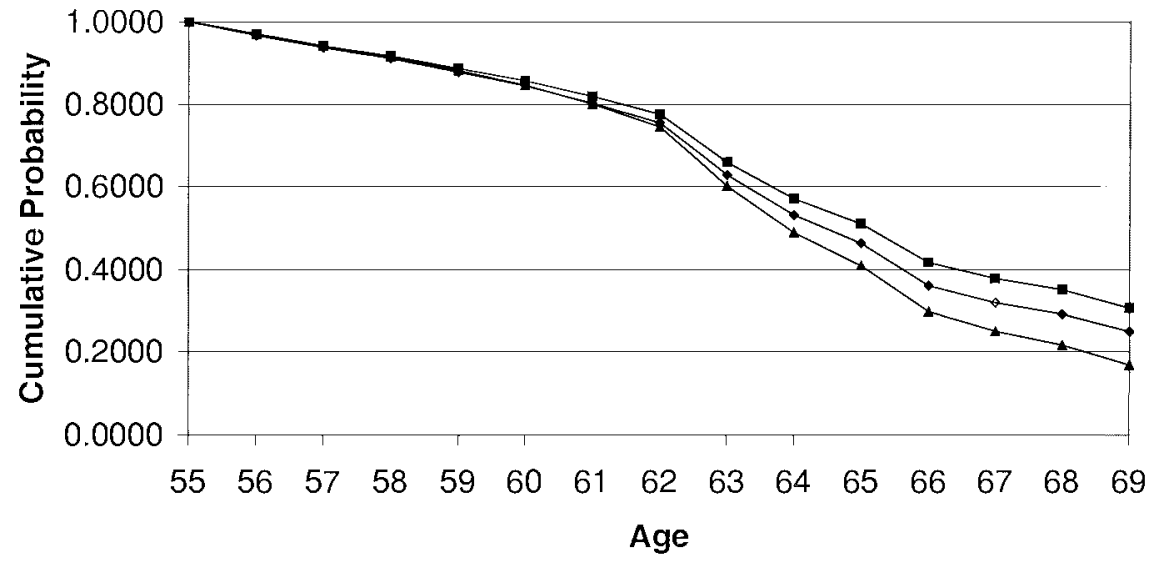

- Baseline CDF $\star-$ Plus 3 Years $\star$ Common Reform

Fig. 12.4 S2 for males, peak value model: $A$, simulated hazard; $B$, cumulative probability

points under S3. The larger reduction in average retirement rate under S3 is not surprising, as this case moves the spikes in the retirement hazard back by three years.

We can assess the wealth and accrual effects underlying these results. This change will have a negative wealth effect on retirement, since this amounts to a benefit cut for any retirement age, which will encourage work. The accrual effects are more complicated: For ages sixty-two to sixty-four, this change will decrease work incentives, as work in these years now only benefits the individual through the dropout year provision and no longer 
A

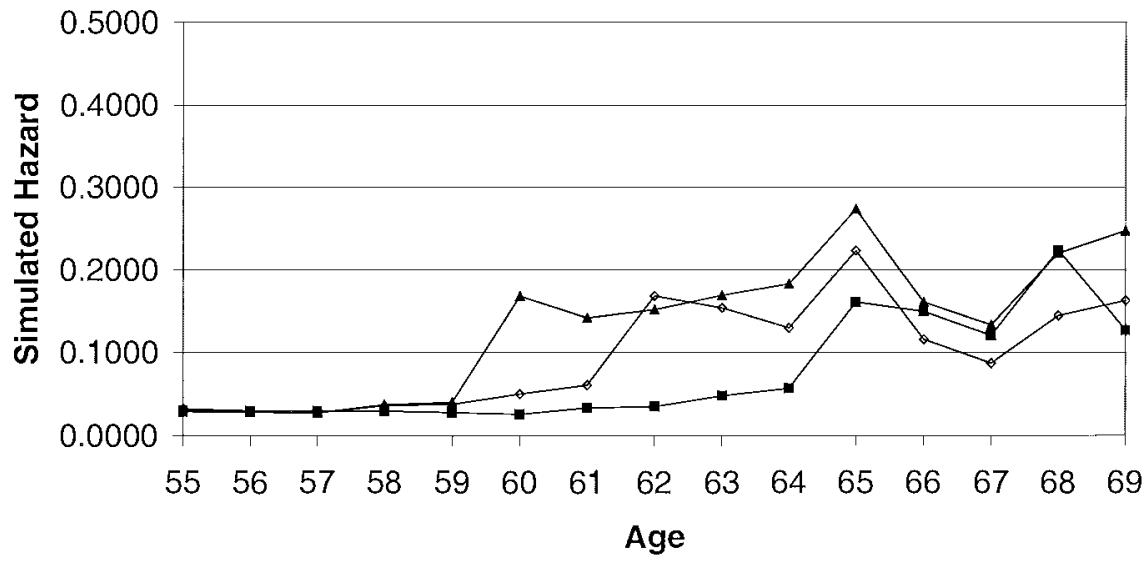

$\rightarrow$ Baseline Hazard $\rightarrow$ Plus 3 Years $\rightarrow$ Common Reform

B

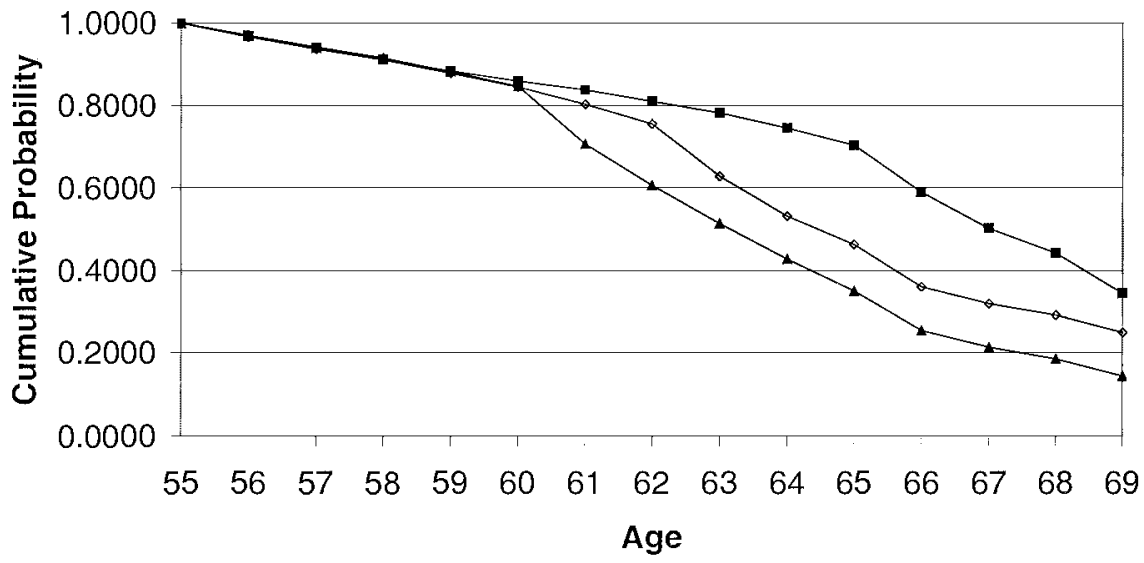

\section{Baseline CDF $\rightarrow$ Plus 3 Years $\rightarrow$ Common Reform}

Fig. 12.5 S3 for males, peak value model: $A$, simulated hazard; $B$, cumulative probability

through a more than fair actuarial adjustment for delayed claiming; and for ages sixty-five to sixty-seven, there will be an increase in work incentives, as the less fair DRC is replaced by the 6.67 percent per year actuarial adjustment. Due to offsetting wealth and accrual effects, there are only modest effects of this change on labor supply when there is no change in retirement norms; however, when a change in retirement norms is applied, the labor supply effects will be substantially larger.

The results of these simulations for the first policy change are clearly visible in figures $12.3-12.11$. In each case, for $\mathrm{S} 1$, there is relatively little im- 
A

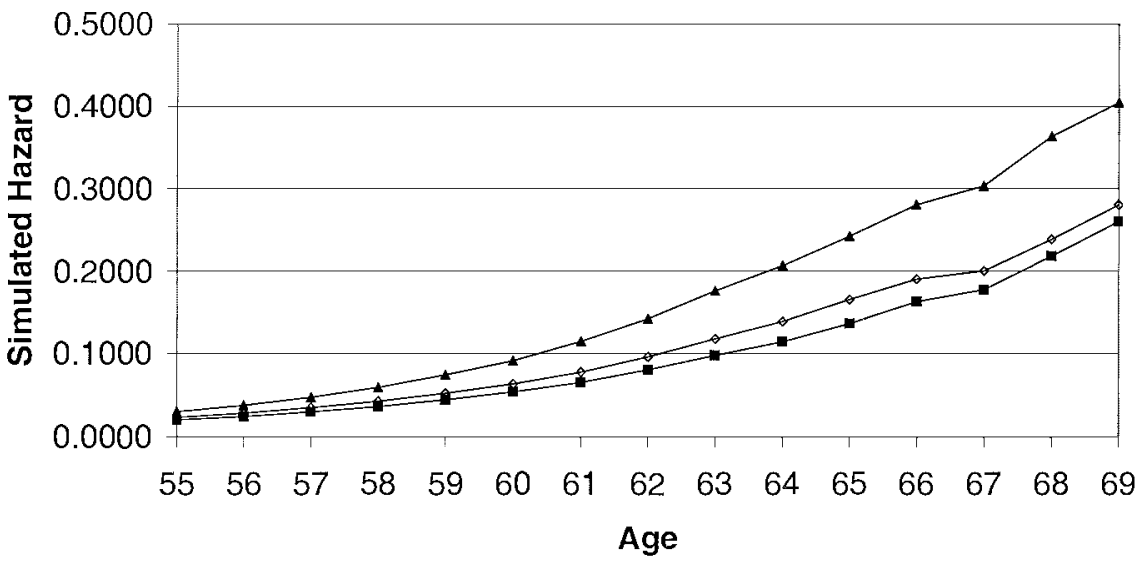

$\rightarrow$ Baseline Hazard $\rightarrow$ Plus 3 Years $\star$-Common Reform

B

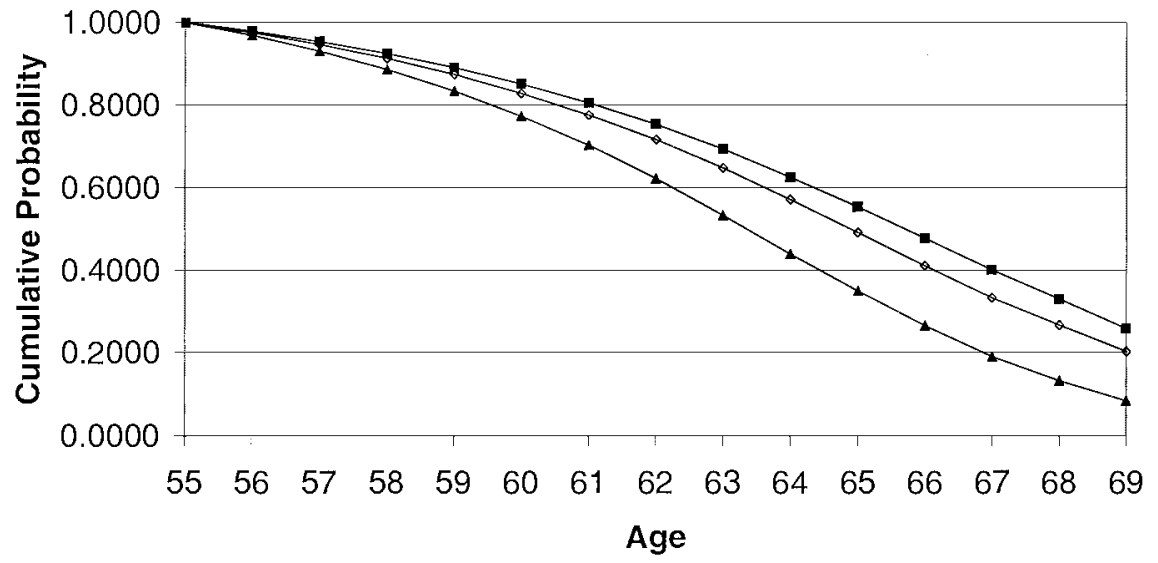

\section{Baseline CDF $\rightarrow$ Plus 3 Years $\rightarrow$ - Common Reform}

Fig. 12.6 S1 for males, option value model: $A$, simulated hazard; $B$, cumulative probability

pact on retirement; the simulated pattern of retirement or labor force participation closely follows the linear baseline model. Similarly, in S2, there is little deviation from the baseline; here, the baseline has a nonlinear shape, as it is allowed to reflect variation in the age pattern according to the model with age dummies. But in S3 there are more significant impacts. Indeed, at age sixty-five, this policy raises the odds of participating in the labor force by about one-half from the baseline. For example, for the option value model, the odds of participating at age sixty-five rise from 0.46 to 0.68 . This is an enormous effect. This effect peaks at age sixty-five and 
A

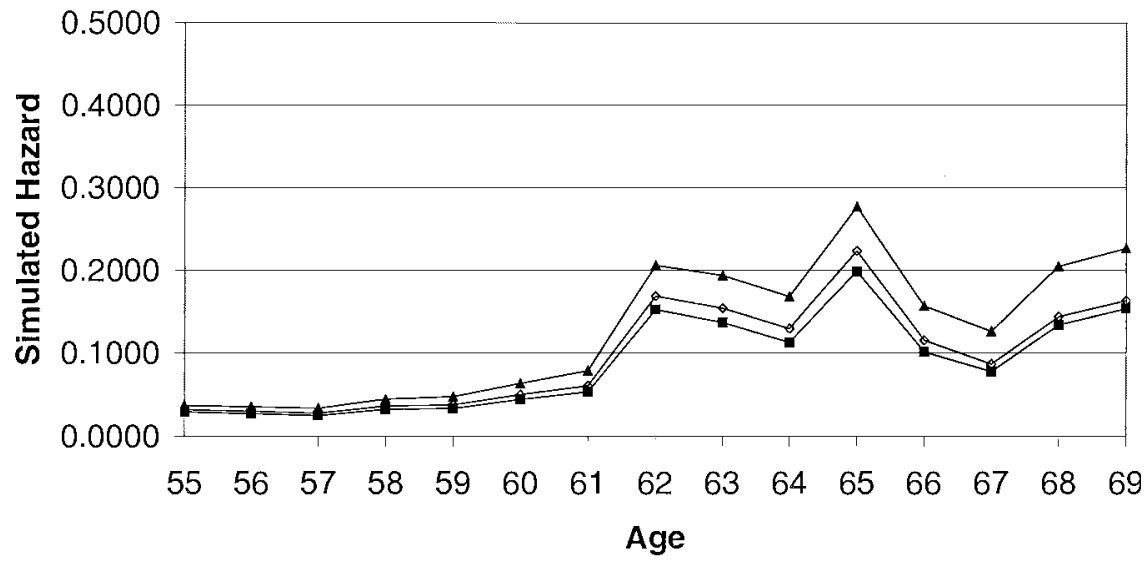

$\rightarrow$ Baseline Hazard $\rightarrow$ - Plus 3 Years $\$$ Common Reform

B

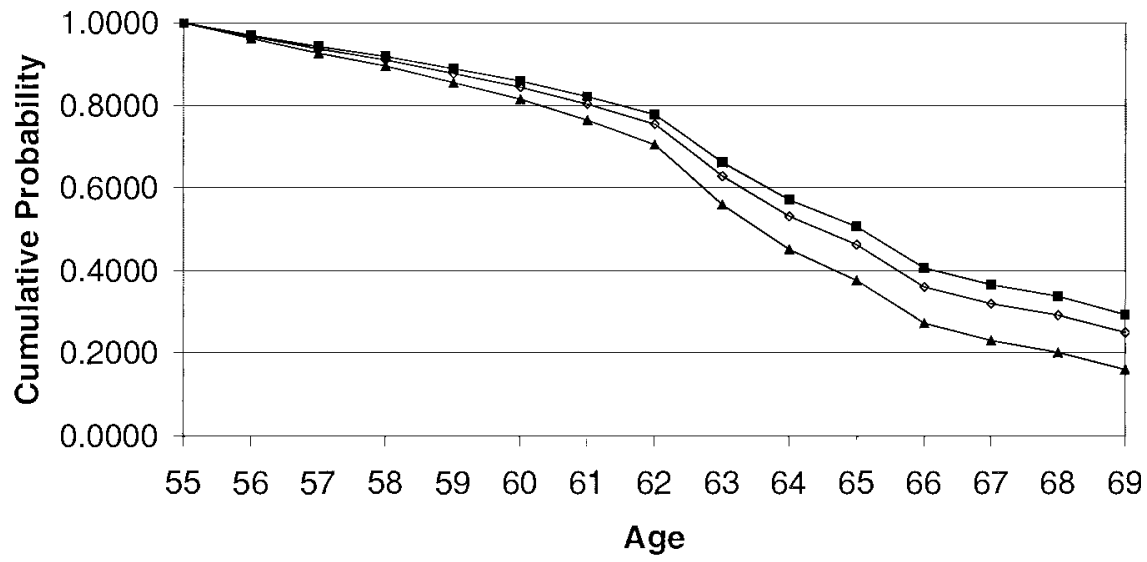

$\rightarrow$ Baseline CDF $\rightarrow$ Plus 3 Years $\rightarrow$ Common Reform

Fig. 12.7 S2 for males, option value model: $A$, simulated hazard; $B$, cumulative probability

then fades over time, as retirement is very high under either model at older ages.

\subsubsection{Common Retirement System}

The second policy change, moving to a flat 60 percent replacementrate benefit with an age sixty early retirement age, has a somewhat different pattern of effects. First of all, it significantly raises, rather than lowering, retirement rates. The policy has the effect of raising both SSW (from $\$ 177,000$ to $\$ 269,000$ for the median man in the sample) and the 
A

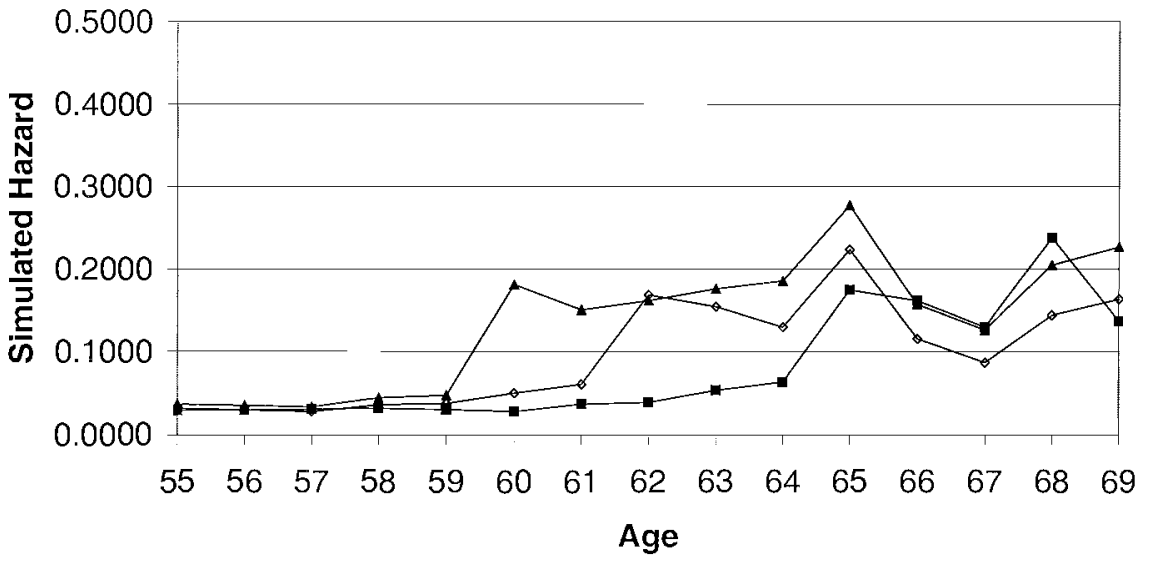

$\rightarrow$ Baseline Hazard $\rightarrow-$ Plus 3 Years $\rightarrow$ Common Reform

B

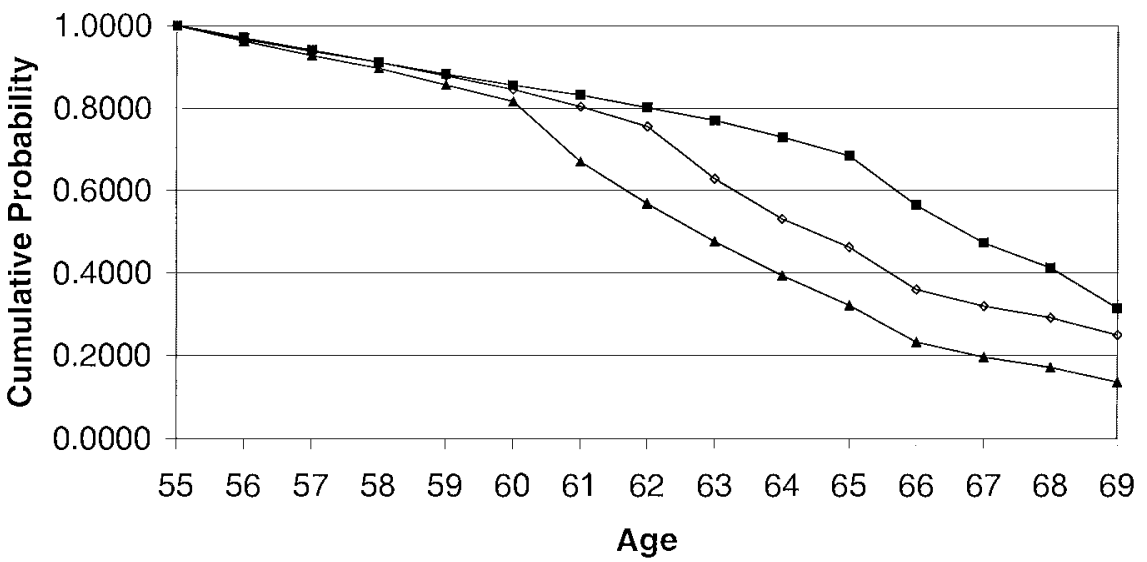

\section{Baseline CDF $\rightarrow$ Plus 3 Years $\rightarrow$ Common Reform}

Fig. 12.8 S3 for males, option value model: $A$, simulated hazard; $B$, cumulative probability

incentive variables (peak value rises from $\$ 13,000$ to $\$ 35,000$ for the median man). Again, there are offsetting wealth and accrual effects, but here the wealth effects are much larger and the result is a much higher retirement rate.

The rise in retirement rates for men ranges from 0.7 percentage points in the peak value model with $\mathrm{S} 2$ to 2.6 percentage points for the option value model with S3. For females, the range is from 2.2 percentage points, with S2, to 3.4 percentage points, with S3. 
A

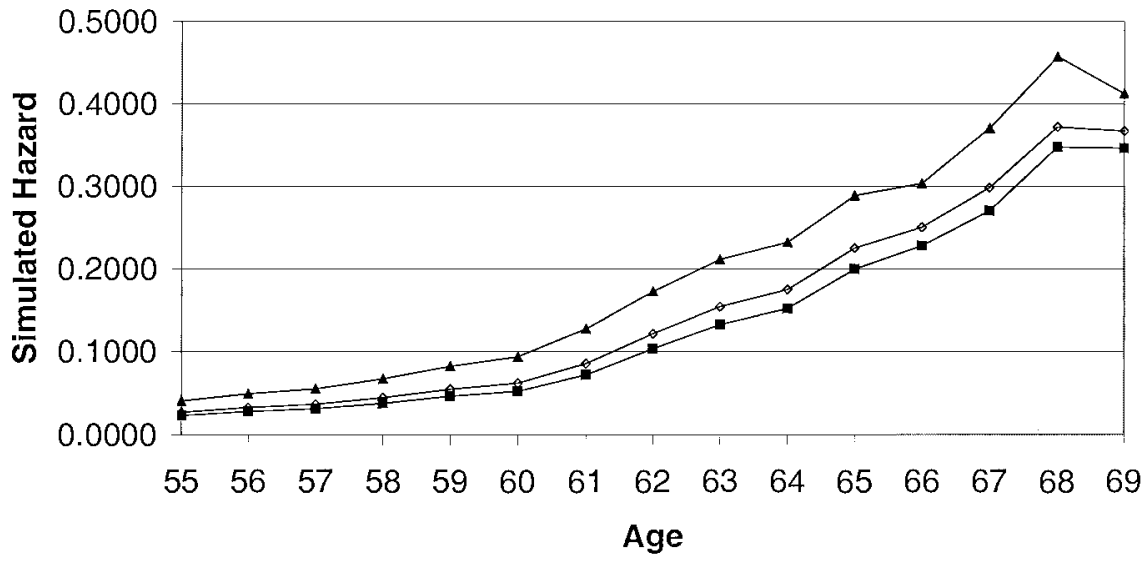

$\rightarrow$ Baseline Hazard $\rightarrow$ Plus 3 Years + - Common Reform

B

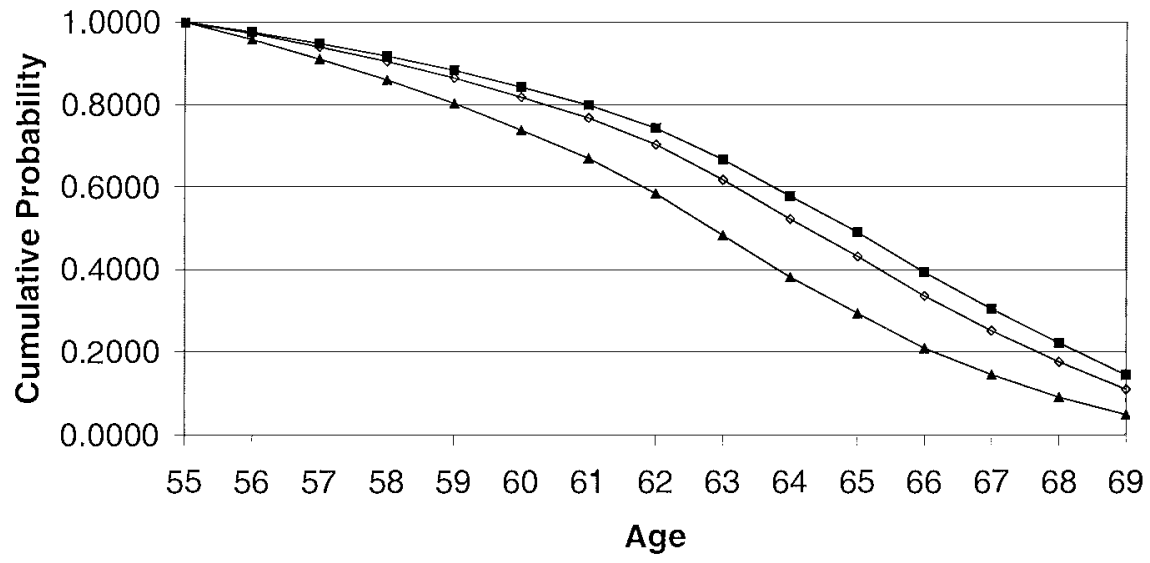

$\rightarrow$ Baseline CDF - Plus 3 Years $₫$ - Common Reform

Fig. 12.9 S1 for females, option value model: $A$, simulated hazard; $B$, cumulative probability

Once again, we show the implications for retirement and cumulative labor force participation at each age in figures 12.3-12.11. In this case, there are fewer differences across our modeling and simulation methods: There is a general finding of a small rise in the hazard rate at all ages. Unlike the effects of the first reform, which fade over time, these impacts are either constant or grow at all ages, reflecting the fact that this policy does not so much shift incentives toward earlier retirement as it does raise the wealth level of retirees at all ages. 

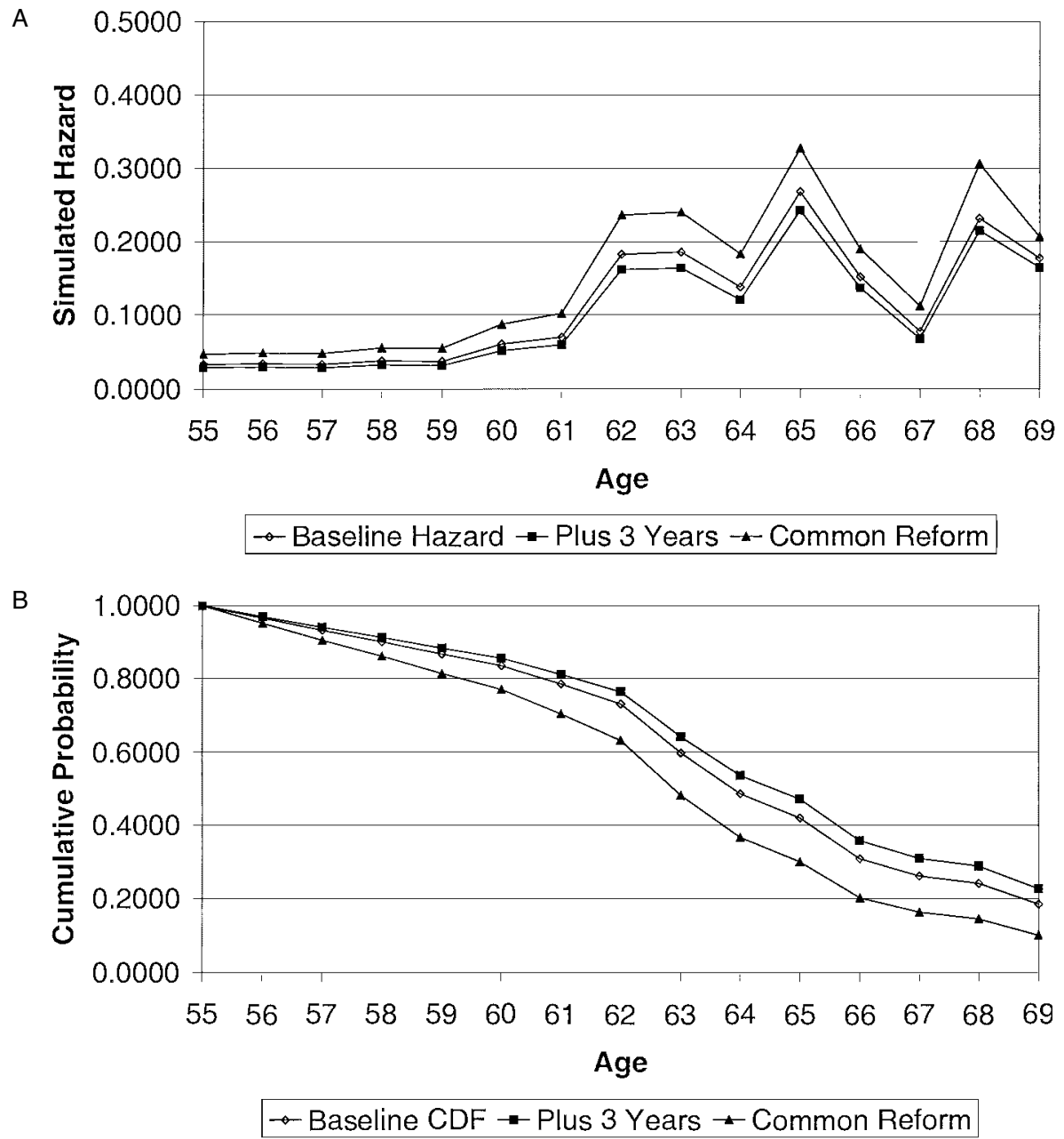

Fig. 12.10 S2 for females, option value model: $A$, simulated hazard; $B$, cumulative probability

\subsection{Conclusion}

The SS program is the most important source of retirement income support for older Americans. As such, it is possible that the incentives embodied in this system for continued work or retirement at various ages are a critical determinant of retirement decisions. Understanding the influence that SS has on retirement decisions is particularly important now, as any reforms to the SS system will change the structure of the program in a manner that has important impacts on retirement incentives.

Our paper has used the richest available current data, the HRS, to pro- 
A

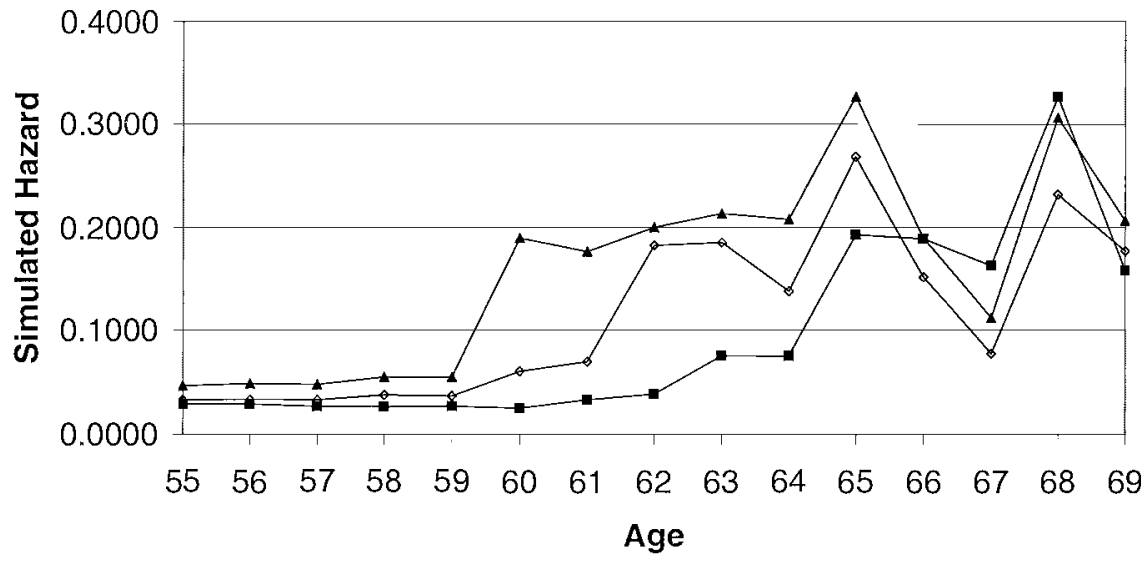

$\rightarrow$ Baseline Hazard - - Plus 3 Years - - Common Reform

B

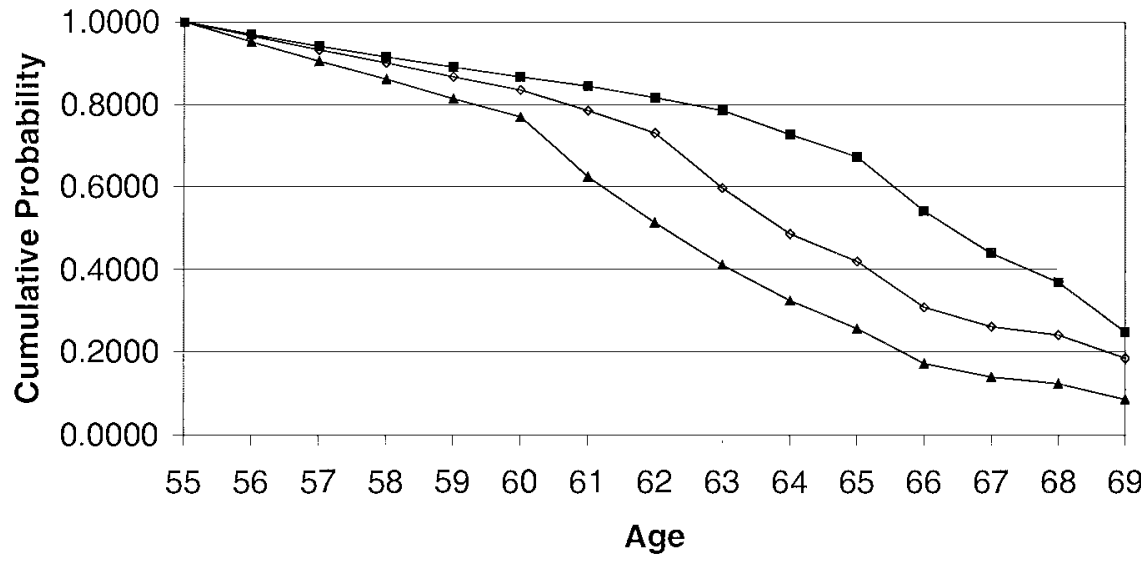

$\rightarrow$ Baseline CDF $\rightarrow$ Plus 3 Years $\rightarrow$ Common Reform

Fig. 12.11 S3 for females, option value model: $A$, simulated hazard; $B$, cumulative probability

vide new evidence on the impact of SS on retirement. We find that retirement decisions appear to be made with reference to the entire stream of future SSW accruals, rather than just the level of wealth or the accrual over the next year, so that forward-looking measures, such as our peak value measure, are important variables to include in retirement models. These forward-looking measures have a significant impact on retirement decisions for men, although for women only the option value model generates significant results. Simulations of policy changes indicate that these changes could have significant impacts on retirement decisions. An in- 
crease in the ERA and NRA could result in a 2 percentage point decrease in the average annual retirement rate if the increase has the effect of changing retirement norms, although the effect would be much smaller if norms are unchanged, due to offsetting wealth and accrual effects. A move to a policy with a 60 percent replacement rate at age sixty-five, a much more generous policy than the current SS system, would have very large wealth effects, raising the average annual retirement rate by $2-3$ percentage points.

\section{References}

Blau, David M. 1994. Labor force dynamics of older men. Econometrica 62 (1): 117-56.

Burtless, Gary. 1986. Social security, unanticipated benefit increases, and the timing of retirement. Review of Economic Studies 53 (5): 781-805.

Burtless, Gary, and Robert Moffitt. 1984. The effect of social security benefits on the labor supply of the aged. In Retirement and economic behavior, ed. Henry Aaron and Gary Burtless, 135-75. Washington, D.C.: Brookings Institution.

Coile, Courtney. 2003. Retirement incentives and couples' retirement decisions. NBER Working Paper no. 9496. Cambridge, Mass.: National Bureau of Economic Research.

Coile, Courtney, Peter Diamond, Jonathan Gruber, and Alain Jousten. 2002. Delays in claiming social security benefits. Journal of Public Economics 84 (3): 357-86.

2000. Social security and retirement. NBER Working Paper no. 7830. Cambridge, Mass.: National Bureau of Economic Research, August.

Coile, Courtney, and Jonathan Gruber. 2001. Social security incentives for retirement. In Themes in the Economics of Aging, ed. David A. Wise. Chicago: University of Chicago Press.

Diamond, Peter, and Jonathan Gruber. 1999. Social security and retirement in the United States. In Social Security and Retirement around the World, ed. Jonathan Gruber and David A. Wise, 437-73. Chicago: University of Chicago Press.

Diamond, Peter, and Jerry Hausman. 1984. Retirement and unemployment behavior of older men. In Retirement and economic behavior, ed. Henry Aaron and Gary Burtless, 97-135. Washington, D.C.: Brookings Institution.

Fields, Gary S., and Olivia S. Mitchell. 1984. Economic determinants of the optimal retirement age: An empirical investigation. Journal of Human Resources 19 (2): 245-62.

Gustman, Alan L., and Thomas L. Steinmeier. 1985. The 1983 social security reforms and labor supply adjustments of older individuals in the long run. Journal of Labor Economics 3 (2): 237-53.

- 1986. A structural retirement model. Econometrica 54 (3): 555-84.

Haider, Steven, and Gary Solon. 1999. Nonrandom selection in the HRS social security earnings sample. University of Michigan, Department of Economics. Unpublished Manuscript.

Hausman, Jerry A., and David A. Wise. 1985. Social security, health status, and retirement. In Pensions, labor, and individual choice, ed. David A. Wise, 159-91. Chicago: University of Chicago Press. 
Hurd, Michael D. 1990. Research on the elderly: Economic status, retirement, and consumption and saving. Journal of Economic Literature 28 (2): 565-637.

Krueger, Alan B., and Jorn-Steffan Pischke. 1992. The effect of social security on labor supply: A cohort analysis of the notch generation. Journal of Labor Economics 10 (4): 412-37.

Lumsdaine, Robin, and David Wise. 1994. Aging and labor force participation: A review of trends and explanations. In Aging in the United States and Japan: Economic trends, ed. Yukio Noguchi and David Wise, 7-42. Chicago: University of Chicago Press.

MaCurdy, Thomas E. 1981. An empirical model of labor supply in a life-cycle setting. Journal of Political Economy 89 (6): 1059-85.

Mitchell, Olivia S., and Gary S. Fields. 1982. The effects of pensions and earnings on retirement. In Research in labor economics, Vol. 5, ed. Ronald Ehrenberg, 115-55. Greenwich, Conn.: JAI Press.

National Center for Health Statistics. 1990. Vital statistics of the United States, 1987. Vol. 2. Washington, D.C.: Washington Public Health Service.

Quinn, Joseph. 1999. Retirement patterns and bridge jobs in the 1990s. Policy brief for the employee benefit research institute. Washington, D.C.: Employee Benefit Research Institute (EBRI).

Ruhm, Christopher. 1995. Secular changes in the work and retirement patterns of older men. Journal of Human Resources 30 (2): 362-85.

Samwick, Andrew A. 1998. New evidence on pensions, social security, and the timing of retirement. Journal of Public Economics 70 (2): 207-36.

Stock, James H., and David A. Wise. 1990a. Pensions, the option value of work, and retirement. Econometrica 58 (5): 1151-80.

1990b. The pension inducement to retire: An option value analysis. In $I_{s}$ sues in the economics of aging, ed. David A. Wise, 205-29. Chicago: University of Chicago Press.

Social Security Administration. 1998. Annual statistical supplement, 1998, to the Social Security bulletin. Baltimore, Mary.: U.S. Department of Health and Human Services.

Sueyoshi, Glenn T. 1989. Social security and the determinants of full and partial retirement: A competing risks analysis. NBER Working Paper no. 3113. Cambridge, Mass.: National Bureau of Economic Research, September.

U.S. Bureau of the Census. 1998. No. 1 population and area: 1790 to 1990. In Statistical abstract of the United States. 118th ed. Washington, D.C.: Bureau of the Census. 
